\section{GREQAM}

Groupement de Recherche en Economie Quantitative d'Aix-Marseille - UMR-CNRS 6579

Ecole des Hautes études en Sciences Sociales Universités d'Aix-Marseille II et III
Document de Travail n$^{\circ} 2011-04$

\title{
Purchasing power parity and the long memory properties of real exchange rates: does one size fit all?
}

\author{
Marcel Aloy \\ Mohamed Boutahar \\ Karine Gente \\ Anne Péguin-Feissolle
}

January 2011 


\title{
Purchasing power parity and the long memory properties of real exchange rates: does one size fit all?
}

\author{
Marcel Aloy* Mohamed Boutahar ${ }^{\dagger} \quad$ Karine Gente $^{\ddagger}$ \\ Anne Péguin-Feissolle ${ }^{\S}$
}

January 25, 2011

\begin{abstract}
This paper examines the time series behavior of monthly bilateral real exchange rates (RER) on a comprehensive sample of 78 industrialized and developing countries, using the U.S. Dollar, the UK Pound and the German Deutsche Mark as numeraires. We suggest a threestep testing procedure based on recently introduced econometric techniques, in order to assess the mean-reverting properties of the RER and to address the question of whether real exchange rates follow a non linear process or a long memory process.

The main results are as follows. Firstly, most of the bilateral real exchange rates under study are not mean-reverting. Secondly, the nonlinear ESTAR type adjustment is far from being prominent. Finally, only few bilateral RER exhibit true long memory mean-reverting properties.
\end{abstract}

Keywords: Fractional Integration; Nonlinear modelling; Mean reverting process; Long-memory process

JEL classification: C12; C22; C32; F30; F31

${ }^{*}$ DEFI, Université de la Méditerranée, Faculté des Sciences Economiques et de Gestion, 14 Avenue J. Ferry, 13621 Aix-en-Provence, FRANCE, Email: marcel.aloy@univmed.fr

†GREQAM, Université de la Méditerranée, Centre de la Charité, 2 rue de la Charite, 13236 Marseille cedex 02, FRANCE, Email: mohammed.boutahar@univmed.fr

${ }^{\ddagger}$ DEFI, Université de la Méditerranée, Faculté des Sciences Economiques et de Gestion, 14 Avenue J. Ferry, 13621 Aix-en-Provence, FRANCE, Email: karine.gente@univmed.fr

${ }^{\S}$ Corresponding author: Anne Péguin-Feissolle, GREQAM, Centre de la Charité, 2 rue de la Charite, 13236 Marseille cedex 02, FRANCE, tel: +33.4.91.14.07.70, fax: +33.4.91.90.02.27, Email: Anne.Peguin@univmed.fr 


\section{Introduction}

Most models of international trade and open economy rest on the hypothesis of purchasing power parity (PPP). At the aggregated level, this hypothesis implies that the nominal exchange rate should converge to the ratio of price levels between two countries, i.e. the real exchange rate (RER) should be a mean-reverting process.

The empirical validity of this PPP assumption remains one of the most active and controversial issues in international economics [Taylor (2006), Taylor and Taylor (2004)]. Empirical methodologies and results are mixed. Generally, the usual unit-root tests conclude that PPP does not hold during the post-Bretton Woods period (see Section 2 for a brief survey). Some potential reasons to explain this puzzle are first that countries under study have very heterogeneous exposure to foreign markets, different commercial links with the leading countries (such as the United States, the United Kingdom, or Germany) and have experienced a variety of exchange rate regimes during the last thirty years. Secondly, it may also be that usual testing techniques are inadequate in presence of non-standard dynamics, such as nonlinearity, structural instability, or long memory processes.

This article addresses these empirical difficulties to check PPP during the post-Bretton Woods period in two ways. First, we use a broader set of countries than the set considered in the literature: we thus consider monthly data on $78 \mathrm{CPI}$-based bilateral real exchange rates of industrialized and developing economies, over the period 1970-2006. For each currency, we consider three bilateral nominal exchange rates, the numeraire being alternatively US Dollar, UK Pound and German Mark. It can be seen that the RER behavior does not only depend on the period and the country under study but also on the numeraire used in computing the bilateral RER: the PPP hypothesis is more likely to occur for countries commercially linked or geographically close to the countries of which the currency is taken as numeraire. Second, we use recent econometric techniques to detect long-memory process or short-memory process with structural breaks. Our sequential testing strategy consists of three steps. First, we test for mean-reversion using the FELW estimator of long-memory parameter and drop from the sample each series which does not follow a mean-reverting process. Second, we determine whether the mean-reverting processes are stationary mean-reverting or not. Third, among non-stationary-mean-reverting processes, we discriminate between true long-memory processes and short-memory processes contaminated by abrupt changes in level. Finally, we compute impulse-response functions in order to evaluate half-lives for those true long memory mean- 
reverting bilateral RER.

The main results are as follows. Firstly, most of the bilateral RER appear to be non mean-reverting processes. Secondly, the nonlinear Exponential Smooth Transition Auto-Regressive (ESTAR) type adjustment is far from being prominent and, finally, only few bilateral RER exhibit true long memory mean-reverting properties. For these true long-memory processes, the half-lives are found to lie between 1 month and 6 years.

The remainder of the paper is as follows. In section 2 , the empirical literature on PPP is briefly reviewed. Section 3 considers the econometric methodologies used in the paper. Section 4 reports the empirical results and section 5 concludes.

\section{Controversies as to the PPP hypothesis in the empirical literature: a selected review}

The breakdown of the Bretton Woods system at the beginning of the 1970s stimulated a large flow of research about the long-run equilibrium level of the RER. On the theoretical side, most of macroeconomic models assume PPP in the short run (Frenkel (1976)) or, at least, in the long-run (Dornbusch (1976)). However, on the empirical side, the validity of the PPP hypothesis remains one of the most active and controversial issues in international economics [Taylor (2003 and 2006), Taylor and Taylor (2004)].

\subsection{The two PPP puzzles}

Since the volatility of nominal exchange rates appears to be more pronounced than the volatility of prices, empirical evidence overwhelmingly led to the PPP being rejected as a short run model of exchange rate. In order to test the validity of the PPP hypothesis as a long run relationship, early studies used standard testing methodologies such as the augmented Dickey-Fuller $(\mathrm{ADF})$ test for a unit root in the real exchange rate. In logarithmic form, the RER $q_{t}$ is defined as:

$$
q_{t}=s_{t}-p_{t}+p_{t}^{*},
$$

where $s_{t}$ is the log of the bilateral nominal exchange rate between the domestic and the foreign country, $p_{t}$ and $p_{t}^{*}$ are respectively the log of the domestic and foreign country price levels. As defined in equation (1), the RER measures the deviation from PPP: under long-run PPP, the logarithm of the RER must display reversion towards zero (after appropriate scaling). 
According to the ADF-test, the RER is supposed to follow a linear autoregressive model that can be reparametrized as:

$$
\Delta q_{t}=\rho q_{t-1}+\sum_{j=1}^{k-1} a_{j} \Delta q_{t-j}+a_{0}+e_{t}
$$

where $\Delta q_{t}=q_{t}-q_{t-1}$ and $e_{t}$ is a white noise disturbance. Under the null hypothesis $H_{0}: \rho=0$, the RER contains a unit-root and displays no meanreversion towards the PPP equilibrium. Using univariate unit root tests, numerous studies of RER in industrialized countries prove incapable of rejecting the null hypothesis for the post-Bretton Woods period when the US dollar is taken as numeraire (see e.g. the numerous references cited in Taylor $(2006))^{1}$. Notably, some other studies find support for PPP when RER is expressed vis-à-vis the German Mark (Chowdhuri and Sdogati (1993), Cheung and Lai (1998 and 2000)) or for high inflation countries (e.g. Choudhry, McNown and Wallace (1991) which use multivariate cointegration analysis). The non-rejection of the unit root hypothesis in the RER is known as the first PPP puzzle (see e.g. Taylor, Peel and Sarno (2001)), since it questions one of the most popular intuitions among economists (Rogoff (1996)).

The second PPP puzzle highlighted in the literature reflects the fact that, among the studies which conclude in favor of RER mean-reversion, the empirical measurement of the half-lives of deviations from PPP is around three to five years (Rogoff (1996)). This high degree of persistence is at odds with the implications of sticky-price models of open economies, which imply that the half-life of a shock to the RER should be less than two years ${ }^{2}$.

Confronted by these two puzzles, three different processes are considered in the empirical literature to model the dynamic behavior of RER.

\subsection{Linear autoregressive model}

The first one is the linear autoregressive model (as described in equation (2)). Following Engle and Granger (1987) terminology, if the RER is found to follow a $I(0)$ - or stationary - process instead of a $I(1)$ - or nonstationary process, it exhibits a geometrical reversion towards the long run equilibrium after a shock. In this case, PPP holds at least in the long run. However, the

\footnotetext{
${ }^{1}$ However, the literature has often pointed out the low power of standard unit-root tests over short time spans of data. Long-span or panel-data studies partly address this criticism.

${ }^{2}$ Some authors have recently discussed the appropriateness of usual measures of halflives and have suggested some alternative measures for assessing the persistence in real exchange rates (see e.g. Chortareas and Kapetanios (2004), El-Gamal and Ryu (2006)).
} 
second puzzle is not solved when autoregressive roots are found to be close to one.

\subsection{Nonlinearity and structural breaks}

The second kind of process considered to model the RER is constituted by various forms of nonlinear models. Most of the literature considers alternatively the band-threshold autoregressive (TAR) model (e.g. Obstfeld and Taylor (1997)), the ESTAR process (e.g. Taylor, Peel, and Sarno (2001)), or the Markov regime switching model (e.g. Kanas (2006)).

These nonlinear models belong to the more general class of structural break models, as illustrated by simple examples (see e.g. Park and Shintani (2005) and Cerrato, Kim and MacDonald (2010) for some extensions). Following the $\mathrm{ADF}$ equation (2), nonlinear and structural break models can be represented by:

$$
\Delta \widetilde{q}_{t}=\beta \widetilde{q}_{t-1} \rho\left(z_{t}, \theta\right)+\sum_{j=1}^{k-1} a_{j} \Delta \widetilde{q}_{t-j}+e_{t},
$$

were $\widetilde{q}_{t}$ is the log of the RER expressed in deviations from the mean, $\rho\left(z_{t}, \theta\right)$ is the transition function, $z_{t}$ is a transition variable and $(\beta, \theta)$ a set of parameters (assuming $\beta<0$ and $\theta>0$ ), both influencing the value of persistence. For instance, in the Self-Exciting Threshold Auto-Regressive (SETAR) model, the transition variable is the (demeaned) RER with lag delay $d \geq 1$, i.e. $z_{t}=\widetilde{q}_{t-d}$, and the transition function can be given as $\rho\left(z_{t}, \theta\right)=1\left\{\widetilde{q}_{t-d} \leq-\theta\right\}+1\left\{\widetilde{q}_{t-d} \geq \theta\right\}$. Conversely, in the ESTAR model, the transition function is given by $\rho\left(z_{t}, \theta\right)=1-\exp \left(-\theta \widetilde{q}_{t-d}^{2}\right)$.

In these SETAR and ESTAR cases, the mean reversion occurs only when the size of the deviation from the long-run equilibrium exceeds a given threshold. For instance, considering the SETAR case, in the central regime $-\theta<\widetilde{q}_{t-d} \leq \theta$, the RER follows an $I(1)$ process since $\rho\left(z_{t}, \theta\right)=0$, while in the outer regimes $\left(\widetilde{q}_{t-d} \leq-\theta\right.$ or $\left.\widetilde{q}_{t-d} \geq \theta\right)$ it follows an $I(0)$ mean-reverting process. In the ESTAR model, the transition between regimes is smooth, with a transition function bounded between 0 and 1 . When the RER deviation from the mean is null $\left(\rho\left(z_{t}, \theta\right)=0\right)$, the RER follows an $I(1)$ process, and the transition towards the outer regime $\left(\rho\left(z_{t}, \theta\right) \neq 0\right)$ occurs when the RER deviates from his mean $\left(\widetilde{q}_{t-d} \neq 0\right)$. In the latter case, the RER follows an $I(0)$ process and the speed of transition towards the outer regime increases with the value of $\theta$. Whilst globally mean-reverting, these nonlinear processes follow a near random walk behavior for sufficiently small deviations from PPP. The ESTAR process becomes increasingly mean-reverting 
with the size of the deviation from the equilibrium. These kinds of processes can be justified by theoretical models introducing transaction costs in international arbitrage ${ }^{3}$ (Dumas (1992), Sercu, Uppal and van Hulle (1995) among others): the costs of trading goods induce persistent deviations from $\mathrm{PPP}$ as long as these deviations are sufficiently small relative to the cost of trading.

In the Markov switching model, the transition function can be defined as $\rho\left(z_{t}, \theta\right)=s_{t}$ were the transition variable $z_{t}=s_{t}$ is an unobservable latent variable following a two-state first-order Markov process, taking the value 0 or 1 . The probability of transition from regime $i$ to regime $j$ is constant and defines a $2 \times 2$ matrix whose elements are given by $p_{i j}=\operatorname{Pr}\left(s_{t}=j \mid s_{t-1}=i\right)$ for $i=0,1$ and $j=0,1$. For instance, when $s_{t}=0$ the RER follows an $I(1)$ process, while when $s_{t}=1$ it follows an $I(0)$ process (given that $\beta<0$ ).

These various processes belong to the general class of structural break models since the regression coefficient $\rho$ (equation (2)) is time-varying ${ }^{4}$.

A first implication of these specifications is related to the first PPP puzzle. Indeed, since the seminal work of Perron (1989), it has been widely recognized that the usual linear unit root tests are biased towards not rejecting a false null of a unit root when the true process is non-linear or when structural breaks are present. To address this problem, recent researches use nonlinear techniques instead of the standard unit root tests. For example, Kapetanios, Shin and Snell (2003) have developed the KSS test, a new unit root test statistic more powerful against a stationary ESTAR process than the standard ADF test ${ }^{5}$. Since linear unit root tests might not be able to discriminate between unit root and nonlinear processes, the KSS test is designed to detect evidence of nonlinear mean reversion for most cases where linear unit root tests fail ${ }^{6}$.

The second implication is related to the second PPP puzzle. The RER half-life -in non-linear or structural breaks models- depends on both the size

\footnotetext{
${ }^{3}$ Others potential sources of nonlinearity in real exchange rates are suggested in the recent literature [Kilian and Taylor (2003), Sarno and Taylor (2001)].

${ }^{4}$ However, in the PPP literature, structural breaks are more often characterized by temporary changes in the mean of the RER (see e.g. Christopoulos and Leon-Ledesma (2010)).

${ }^{5}$ Other testing methodologies are provided by Bec et al. (2004), Park and Shintani (2005) and Kruse et al. (2009).

${ }^{6}$ For instance, using monthly real effective exchange rates for 52 countries over the period 1994-2007, Bahmani-Oskooee, Hegerty and Kutan (2008) conclude that 11 currencies are stationary (at the 10 percent level of significance) according to the KSS test whereas only 5 currencies were supposed to be stationary according to the ADF statistic (without trend).
} 
of the shock and the initial conditions. For instance, Taylor, Peel and Sarno (2001) found that the ESTAR model is consistent with half-lives lying in the range of three to five years for small and near PPP equilibrium shocks. Conversely, the speed of mean reversion is found to be substantially faster for larger shocks.

Since non linearity is likely to solve the two PPP puzzles, numerous recent papers (Cerrato, Kim and MacDonald (2010), Dufrénot et al. (2006, 2008), Kiliç (2009), McMillan (2009) among many others) have emphasized the nonlinear mean reverting hypothesis. However, as it is discussed in the following section, nonlinear models may be spuriously selected, in so far as they can easily be confused with long memory processes.

\subsection{Long-memory}

Finally, the third kind of process used to model the RER dynamics is the long memory case. Granger and Joyeux (1980) showed the usefulness of distinguishing between integer and fractional integration. The order of integration of a so-called fractionally integrated process is a non-integer number, usually denoted by $d$ : if $d>0$ the process has long memory properties; it is stationary if $d$ lies in the interval $(0,0.5)$ and mean reverting if $d<1$. Therefore a time series can be neither $I(0)$ nor $I(1)$, questioning the relevance of the usual unit-root tests to detect stationarity. In this respect, Lee and Schmidt (1996) have shown that the KPSS test - initially developed to test for an $I(0)$ null hypothesis against an $I(1)$ alternative - can be relevant to distinguish short memory from long memory stationary processes, since this test is shown to be consistent against an $I(d)$ alternative.

The long-memory hypothesis may be relevant in the PPP debate since temporal aggregation ${ }^{7}$ (Taylor (2001)) or cross-sectional aggregation ${ }^{8}$ (Imbs et al. (2005)) are found to induce a positive bias in the computed aggregate half-lives. In the long-memory literature, it has been demonstrated (see for instance Haubrich and Lo (1989) and the discussion in Diebold and Inoue (2001)) that aggregation may be a source of long-term dependence. Fractional integrated processes exhibit a hyperbolic reversion towards the long-run equilibrium after a shock, provided that $0<d<1$ : the meanreversion rate is a decreasing function of time since the shock. In consequence, the usual half-life measure should be completed with more general $m$-lives computations.

\footnotetext{
${ }^{7}$ When the RER follows a first-order autoregressive at a higher frequency than that at which the data is sampled.

${ }^{8}$ Aggregating across different goods characterized with different speeds of reversion.
} 
Papers testing long-memory in the field of the PPP hypothesis (Baum, Barkoulas and Caglayan (1999), Cheung and Lai (2005), Gil-Alana (2000), Gil-Alana and Toro (2002), Holmes (2002), Villeneuve and Handa (2006)) report very mixed results.

Moreover, some papers [Diebold and Inoue (2001), Granger and Hyung (2004) and Smith (2005)] have shown that the estimation of the long memory parameter $d$ may be biased in presence of structural changes or regime switches. Conversely, Granger and Hyung (2004) underline the fact that fractional integration causes multiple breaks in the series (depending on the value of $d$ ) to be detected spuriously by usual estimation methods.

Since the presence of structural breaks may generate spurious long memory, the crucial question is to determine whether RER follows a true long memory process or a nonlinear mean reverting process such as ESTAR, timevarying STAR (Sollis (2008)) or Markov switching processes (Bergman and Hansson (2005), Kanas (2006)). In this respect, Perron and Qu (2004 and 2010) propose a simple testing procedure to distinguish between short memory contaminated by structural change and true long memory process. To our knowledge, this new test has not yet been applied on RER series except in McMillan (2009) where only five monthly real exchange rates against the US dollar were considered, namely, Canada, Germany, Japan, Switzerland and the UK.

These different cases have not been considered in a unified framework in the literature. The contribution of this article is to propose a general testing framework to discriminate between these competing models. To investigate more precisely the mean-reverting behavior of RER (i.e. the PPP hypothesis), this paper considers a variety of different tests, some of which have only recently been developed: the Kwiatowski et al. (1992) test (KPSS), in order to test for a $I(0)$ null hypothesis against a $I(d)$ alternative, the Kapetanios, Shin and Snell (2003) test (KSS) to analyze nonstationarity against a stationary ESTAR process, the Robinson's (1994) test to detect fractional integration and the Perron and $\mathrm{Qu}$ tests $(2004,2010)$ to discriminate between a true long-memory process and a short memory process contaminated by structural changes in level. Finally, we compute impulse-response functions in order to evaluate half-lives for those true long memory mean-reverting bilateral RER. 


\section{Econometric methodology}

\subsection{Estimation of the long memory parameter}

Concerning the estimation methods of the long memory parameters $d$, there exist different techniques (Geweke and Porter-Hudak (1983) and Robinson (1995), among others). Here, we use the Feasible Exact Local Whittle (FELW) estimator developed by Shimotsu $(2006)^{9}$. It is an extended version of the exact local Whittle (ELW) estimator proposed by Shimotsu and Phillips (2004, 2005 and 2006), that is a semiparametric estimator generally giving a good estimation method for the memory parameter in terms of consistency and limit distribution, except in the case where the mean is unknown. To overcome this difficulty, Shimotsu (2006) extended the ELW estimator to the FELW estimator and showed that this estimator is consistent and has an $N\left(0, \frac{1}{4}\right)$ limit distribution for $d \in\left(-\frac{1}{2}, 2\right)$.

\subsection{Robinson's test of fractional integration}

We know that a time series $y_{t}$ follows an $\operatorname{ARFIMA}(p, d, q)$ (Autoregressive Fractionally Integrated Moving Average) process if

$$
\Phi(L)(1-L)^{d} y_{t}=\mu+\Theta(L) \varepsilon_{t},
$$

where

$$
\Phi(L)=1-\phi_{1} L-\ldots-\phi_{p} L^{p}, \Theta(L)=1+\theta_{1} L+\ldots+\theta_{q} L^{q},
$$

$L$ is the Backward shift operator i.e. $L y_{t}=y_{t-1}$, and $\varepsilon_{t} \sim i i d\left(0, \sigma^{2}\right)$. Different cases are possible, depending on the value of the long memory parameter $d$; for example, $y_{t}$ is stationary and possesses shocks that disappear hyperbolically when $0<d<1 / 2$, whereas it is nonstationary and mean reverting for $1 / 2 \leq d<1$.

We use the methodology elaborated by Robinson (1994) for testing unit root and other nonstationary hypotheses. Let us consider the null hypothesis defined by

$$
H_{0}: \theta=0
$$

in the model given by:

$$
y_{t}=\beta^{\prime} z_{t}+x_{t}
$$

\footnotetext{
${ }^{9}$ We use the code available from K. Shimotsu at

http://qed.econ.queensu.ca/faculty/shimotsu/programs/elwcode.zip
} 
and

$$
(1-L)^{d+\theta} x_{t}=u_{t}
$$

for $t=1,2, \ldots$, where $y_{t}$ is the observed time series, $z_{t}$ is a $k \times 1$ vector of deterministic regressors, $u_{t}$ is a (possibly weakly autocorrelated) $I(0)$ process, and $d$ is a real parameter. Robinson (1994) proposes a Lagrange Multiplier (LM) statistic, called $\widehat{r}$ (see Appendix 1 for details), and shows that it has a standard asymptotic distribution under some regularity conditions:

$$
\widehat{r} \underset{d}{\longrightarrow} N(0,1) \quad \text { as } T \longrightarrow \infty .
$$

Thus, it is a one-sided test of $H_{0}: \theta=0$ : we reject $H_{0}$ against $H_{1}: \theta>0$ if $\widehat{r}>z_{\alpha}$ and against $H_{1}: \theta<0$ if $\widehat{r}<-z_{\alpha}$, where the probability that a standard normal variate exceeds $z_{\alpha}$ is $\alpha$.

This Robinson (1994)'s test has been used in several papers in order to detect fractional integration (Caporale and Gil-Alana (2007a, b and c), GilAlana and Nazarski (2007)), fractional integration with nonlinear models (Gil-Alana and Caporale (2006), Cunado, Gil-Alana and Perez de Gracia (2007)) and fractional integration with structural breaks (Caporale, Cunado and Gil-Alana (2007), Gil-Alana (2008)).

\subsection{The KSS test}

The KSS test elaborated by Kapetanios, Shin and Snell (2003) aims to analyze nonstationarity under the null hypothesis against nonlinear but globally stationary ESTAR process under the alternative. The ESTAR model is given by

$$
\Delta y_{t}=\phi y_{t-1}\left[1-\exp \left(-\gamma y_{t-1}^{2}\right)\right]+\varepsilon_{t}
$$

where $\gamma$ is the smoothness parameter. A Taylor approximation of the transition function around $\gamma=0$ leads to the auxiliary regression:

$$
\Delta y_{t}=\psi y_{t-1}^{3}+u_{t}
$$

where $y_{t}$ is the demeaned or detrended data. The null and alternative hypotheses are: $H_{0}: \psi=0, \quad H_{1}: \psi<0$ and the test statistic, whose critical values are given in Kapetanios, Shin and Snell (2003), is written as

$$
t_{\psi=0}=\frac{\widehat{\psi}}{\sigma_{\widehat{\psi}}} .
$$


In the general case where the errors are autocorrelated, equation (11) is extended to:

$$
\Delta y_{t}=\psi y_{t-1}^{3}+\sum_{i=1}^{m} \rho_{i} \Delta y_{t-i}+u_{t} .
$$

The lag length $(m)$ is chosen by assessing the significance of the augmented coefficients.

In this paper, we estimate the $t_{\psi=0}$ statistic using only demeaned and not detrended, data: under the null, the real exchange rate follows a simple random walk.

\subsection{Perron and Qu test}

Perron and $\mathrm{Qu}$ (2004 and 2010) develop a simple test based on the log periodogram estimator proposed by Geweke and Porter-Hudak (1983); they show how the distribution of this estimator is highly dependent on the number of frequencies used, especially when the data generating process is a stationary short memory process contaminated by structural changes in level. This test is thus helpful to distinguish structural change from long memory.

Let $\widehat{d}_{a}$ (respectively $\widehat{d}_{b}$ ) denote the log periodogram estimate of the memory parameter when $m_{a}=\left[T^{a}\right]$ (respectively $m_{b}=\left[T^{b}\right]$ ) frequencies are included in the regression. Under the null hypothesis of a stationary Gaussian fractionally integrated process, if $0<a<b<1$ and $a<4 / 5$, Perron and $\mathrm{Qu}$ $(2004,2010)$ demonstrate that the test statistic follows a Gaussian process under the null:

$$
\sqrt{\frac{24\left[T^{a}\right]}{\pi^{2}}\left(\widehat{d}_{a}-\widehat{d}_{b}\right)} \stackrel{d}{\longrightarrow} N(0,1) .
$$

To test whether the process is a true long memory and not a short-memory process with level shifts, they use this statistic with $a=1 / 2$ and $b=4 / 5$. They note that it is not sensitive to the value of $d$ even if $d>1 / 2$, and is consistent against a short memory process with level shifts or a long-memory process with a strongly mean reverting component.

\subsection{Impulse response functions and half-life analysis}

One way to estimate the persistence of the different series is to fit an ARFIMA model to $y_{t}$ and to estimate its impulse response function. By allowing the long memory parameter $d$ to take non-integer values, the fractional model accommodates a broader range of low-frequency, mean-reverting dynamics than standard time series models. 
The mean-reverting property holds if $d<1$ whereas the impact of a shock is known to persist forever in case of a unit-root process $(d=1)$. This can be seen from the moving average representation for $(1-L) y_{t}$ :

$$
(1-L) y_{t}=A(L) \varepsilon_{t}
$$

with

$$
\begin{aligned}
A(L) & =(1-L)^{1-d} \Psi(L) \\
& =1+a_{1} L+a_{2} L^{2}+\ldots .
\end{aligned}
$$

and $\Psi(L)=\Phi(L)^{-1} \Theta(L)=1+\psi_{1} L+\psi_{2} L^{2}+\ldots$, where $\Phi$ and $\Theta$ are defined in (5). The moving average coefficients $a_{j}, j=1, \ldots$, are referred to as the impulse responses and can be computed as follows:

$$
a_{j}=\sum_{k=0}^{j} \frac{\Gamma(k+d-1)}{\Gamma(d-1) \Gamma(k+1)} \psi_{j-k},
$$

where the $\left(\psi_{j}\right)$ can be computed recursively:

$$
\begin{aligned}
& \psi_{0}=1 \\
& \psi_{j}=\theta_{j}+\sum_{i=1}^{\min (j, p)} \phi_{i} \psi_{j-i} \text { if } 1 \leq j \leq q \\
& \psi_{j}=\sum_{i=1}^{\min (j, p)} \phi_{i} \psi_{j-i} \text { if } j \geq q+1 .
\end{aligned}
$$

The cumulative impulse response function over $j$ periods of time is given by

$$
C_{j}=1+a_{1}+\ldots+a_{j}
$$

and it tracks the impact of a unit innovation at time $t$ on the long run equilibrium relationship at time $t+j$. As $j \rightarrow \infty, C_{\infty}=A(1)$, measuring the long-run impact of the innovation (Campbell and Mankiw (1987)). Cheung and Lai (1993) show that for $d<1, C_{\infty}=0$, implying shock-dissipating behavior. Conversely for $d \geq 1, C_{\infty} \neq 0$, the effect of a shock will not die out. Mean reversion (i.e. $C_{\infty}=0$ ) occurs as long as $d<1$. A measure of persistence usually considered in the literature is the half-life, which indicates how long it takes after a unit shock to dissipate by half on the long-run equilibrium. The half-life can be computed from the $C_{j}$ function as $t=h$ such that $C_{h}=0.5$. 
For ARMA models, an analytical expression for the half-life can be derived; for example, it is well known that the half-life of the $A R(1)$ model $y_{t}=\phi y_{t-1}+\varepsilon_{t}$ is given by $h=-\log (2) / \log (\phi)$. However, for the ARFIMA model, the half-life remains difficult to compute. This problem can be solved plotting the impulse response function and using linear interpolation.

\section{Purchasing Power Parity: empirical analysis}

\subsection{The data}

We consider the log-transformed monthly data over the period November 1970 - August 2006, that is a sample size of 430 observations. The different series are the CPI-based bilateral real exchange rates of 78 countries against the U.S. Dollar, the UK Pound and the German Deutsche Mark (Euro since January 1999). All the observations are computed using series obtained from the International Financial Statistics database. Appendix 2 contains the list of countries. Since this paper focuses mainly on the fractional integration hypothesis, detailed results are given only for countries for which the long memory parameter estimator is significantly lower than unity.

\subsection{Empirical results}

\subsubsection{Integration analysis}

For each time series we perform the following three steps (see Diagram 1):

Step 1. We compute the FELW estimator developed by Shimotsu (2006), $\widehat{d}_{w}$. If $\widehat{d}_{w}$ is significantly greater than 1 (in the sense that $d_{u}$, the upper bound of the $95 \%$ confidence interval, is greater than 1), then the series is not mean reverting and hence is discarded (Figures 1-3 present the results for the whole dataset). According to this test, there remain 39 bilateral real exchange rates over $234^{10}$ : for these series, the PPP holds since the real exchange rates are mean reverting and follow a linear or nonlinear, stationary or nonstationary process. In order to characterize more precisely the dynamics of the corresponding real exchange rates, we perform the next two steps.

Step 2. We perform the KPSS test for unit root, where the null hypothesis is the stationarity. If the null is rejected then the series may follow

\footnotetext{
${ }^{10}$ The whole sample includes 234 real exchange rates series: 78 countries and 3 numeraires.
} 
a long memory process with a parameter $0.5 \leq d<1$ (nonstationary and mean-reverting) or a stationary with structural change in the level (34 real exchange rates are found to be in this case).

Step 3. If the null of stationarity is rejected in step 2, we apply the KSS test to check if the series has a smooth change in the level (ESTAR) and the Perron and Qu (2004 and 2010) test to decide if the series is a true long memory or a short memory contaminated by abrupt changes in the level. When the true long memory hypothesis is not rejected, the FELW estimator of Shimotsu (2006), $\widehat{d}_{w}$, and the Robinson (1994) estimator $d_{R}$ are used to estimate the corresponding degree of fractional integration.

\section{[Insert Diagram 1 here]}

The results of the KPSS test over the 39 series selected in Step 1 are depicted in Table 1: it is worth noting here that, in the first step, only 8 bilateral real exchange rates are found to satisfy the PPP hypothesis when the US Dollar is taken as numeraire, whereas this specific case is the most frequently used in the empirical literature. In the second step, the null hypothesis of the KPSS test is rejected for most of these series in level. The exceptions are Mexico with the US Dollar as numeraire, New Zealand, Belgium, France, and the Netherlands with the German Deutsche Mark/Euro as numeraire: in these five cases, the real exchange rates are thus found to be stationary mean-reverting processes, i.e. the PPP hypothesis is verified with a degree of integration $d<0.5$.

\section{[Insert Table 1 here]}

In the third step, after discarding the five stationary mean-reverting series, we apply the KSS test on the 34 remaining series (Table 2): the null hypothesis of unit root appears to be firmly rejected (at the $1 \%$ level) in 10 cases over 34, against the ESTAR alternative: Bolivia, Brazil and Costa Rica with the US Dollar as numeraire; Australia, Bolivia and Mexico with the UK Pound as numeraire; Turkey, Bolivia, Brazil and Costa Rica with the German Deutsche Mark/Euro as numeraire. In these cases, we can infer that the real exchange rate is likely to follow:

(i) an ESTAR process (or, more generally, a short memory process contaminated with level shifts);

(ii) or a true long memory process (spuriously confused with an ESTAR process), since it is known that fractional integration causes many breaks in 
the series and can spuriously be confused with a short memory process with breaks.

\section{[Insert Table 2 here]}

In order to discriminate between these two hypotheses, we apply the Perron and Qu (2004 and 2010) test: Table 3 shows the results of these tests, where $p_{P Q}$ is the p-value.

[Insert Table 3 here]

Concerning the 34 real exchange rates selected in step 2, we thus find strong evidence in favor of fractional integration and mean reversion: the Perron and $\mathrm{Qu}$ test $p$-values conclude in acceptance that the process generating the series is a true long memory process without level shifts in nearly all cases, with the exception of the five following ones: Brazil for real bilateral exchange rate against the U.S. Dollar, Malta, Mexico and Tunisia, for real bilateral exchange rate against the UK Pound, and Brazil, for real bilateral exchange rate against the German Deutsche Mark.

For these five countries, we have $p_{P Q}<0.10$ : the value of $p_{P Q}$ is thus consistent with a short memory process with level shifts and not a true long memory process. Taking into account the preceding KSS tests results, we can conclude that the ESTAR (or more generally the short memory with breaks) hypothesis is likely to be satisfied only in the following three cases: Brazil when the US Dollar is the numeraire, Mexico when the UK Pound is the numeraire, and Brazil when the German Deutsche Mark/Euro is the numeraire. This finding questions the relevance of the results obtained in most of the recent empirical literature (e.g. Taylor, Peel and Sarno (2001)).

The results of the Perron-Qu significance levels and the upper-bounds of the $95 \%$ intervals on the long memory parameters for the whole dataset are depicted in Figures 1 to 3. These figures show clearly that most of the bilateral CPI-based real exchange rates follow a long memory - nonstationary and non-mean reverting - process, more particularly when the US Dollar is taken as numeraire.

$$
\begin{aligned}
& \text { [Insert Figure } 1 \text { here] } \\
& \text { [Insert Figure } 2 \text { here] } \\
& \text { [Insert Figure } 3 \text { here] }
\end{aligned}
$$

Finally, Table 4 collects the results of the fractional integration against respectively the U.S. Dollar, the U.K. Pound and the German Deutsche 
Mark: $\widehat{d}_{w}$ is FELW estimator of the fractional integration parameter; $d_{l}$ and $d_{u}$ are the lower and upper bounds of the $95 \%$ confidence intervals ( $m$ is chosen to be $m=T^{0.65}$ with $T$ is the sample size and the lower and upper bounds on the long memory parameter are respectively -0.2 and 1.4$) ; d_{R}$ is the value of the long memory parameter $d$ corresponding to the absolute value of the minimum of the Robinson (1994) test statistic. The Robinson's (1994) test confirms the results of our first step selection procedure since $d_{R}<1$ in all cases.

[Insert Table 4 here]

\subsubsection{Half-life analysis}

In order to model the exchange rates with ARFIMA models, i.e. to determine which might be the best way to characterize the behavior of the series, we start from a most general specification and we determine plausible specifications, depending on the significance of the parameters and the usual diagnostic tests ${ }^{11}$. For true long-memory processes $\left(p_{P Q}>0.10\right)$, we compute and plot impulse-response functions to evaluate half-lives (Figures 4 to 6$)$.

\section{[Insert Figure 4 here] \\ [Insert Figure 5 here] \\ [Insert Figure 6 here]}

The Table 5 collects half-lives for bilateral real exchange rates with respect to US Dollar, UK Pound and German Deutschemark. For some countries (Bolivia, Brazil, Costa Rica and Peru), the real exchange rates follow a long memory mean reverting process whatever the numeraire is. We pick the US Dollar as numeraire for these countries because they experiment a stronger commercial link with the USA than with European countries; therefore, the Table 5 concerns only 19 countries.

\section{[Insert Table 5 here]}

In the literature, when PPP holds, half-lives are generally found to be between 1.5 and 3 years [Cheung and Lai (2000)], in accordance with the price stickiness hypothesis. Gil-Alana and Toro (2002), by means of ARFIMA models, examined the real exchange rates in five developed countries and

\footnotetext{
${ }^{11}$ To save space, we display only the estimation of the fractional integration parameters. The results of the estimation of the ARMA components are available upon request.
} 
conclude that, for all countries, there is evidence of mean reversion behavior; moreover, Italy and Japan seem to follow non-stationary processes while the exchange rates in the UK, Canada and France appear as stationary but with a long memory behavior. We show that the half-lives lie between 1 month and 6 years (Gil-Alana and Toro (2002) compute the half-lives in the case of five developed countries and conclude that the half-lives are above 7 years). Our results are in line with Cheung and Lai (2000) for Costa Rica, Venezuela, New Zealand, Turkey, Swaziland, Belgium. Faster convergence is observed for Bolivia, Peru, Austria, Denmark, Luxembourg, The Netherlands and Switzerland. Slower convergence is observed for Australia, The Ivory Coast and Nepal. According to Engel and Morley (2001), convergence to PPP level is mainly driven by nominal exchange rate changes. Even if the exchange rate regime does not influence the validity of PPP (Drine and Rault (2008)), it may affect the speed of convergence towards the long-run equilibrium. We can notice among faster convergence countries the presence of European Monetary Union countries (Luxembourg, Netherlands) and European countries that did not adopt the Euro as their currency (Denmark, which participates in the European Exchange Rate Mechanism II), or countries which do not belong to European Monetary Union (Switzerland). This may suggest that convergence to PPP is not so different between countries with flexible nominal exchange rate (Switzerland), semi-flexible nominal exchange rate (Denmark) and countries with fixed exchange rates (Netherlands, Luxembourg).

\section{Concluding remarks}

The empirical literature relating to the PPP hypothesis emphasizes two puzzles, namely the controversial findings about the mean reversion of RER towards the equilibrium and the high degree of persistence of the RER. In this respect, three main models (linear autoregressive, nonlinear or structural break, and long memory) are prominent and lead to different conclusions: empirical evidence is mixed and appears to be generally specific to the chosen period and country. It is worthwhile noting that most studies focus on specific hypotheses and ignore the other competing models: the contribution of this article is to propose a general testing framework to discriminate between these different possibilities. In order to do so, we develop a unified sequential strategy proceeding in three steps.

Based on 78 monthly CPI-based bilateral RER for industrialized and developing countries over the period 1970-2006, our results show that there 
is "no one-size fits all model".

Firstly, the time series properties of RER appears to be not only period and country-specific but also specific to the numeraire used in the calculation of the bilateral RER: the PPP hypothesis would be more likely to occur for countries commercially linked or geographically close to the countries of which the currency is taken as numeraire. This question is left for future research.

Secondly, among the numerous countries under study, only few bilateral RER exhibit true long memory mean-reverting properties according to Robinson's and Perron and Qu's tests. In these cases, the half-lives are found to lie between 1 month and 6 years.

Finally, the ESTAR hypothesis, although extensively studied in the recent literature, is only confirmed in three cases: Brazil when the US Dollar is the numeraire, Mexico when the UK Pound is the numeraire, and Brazil when the German Deutsche Mark/Euro is the numeraire. We are thus led to think that the nonlinear models are often spuriously selected, as far as the long memory processes may cause breaks in the series, which can be confused with nonlinear processes.

Acknowledgments: The authors are deeply indebted to Luis A. GilAlana for providing various FORTRAN programs for the Robinson test (1994), that they translated into GAUSS. 


\section{References}

[1] Bahmani-Oskooee M., Hegerty S.W., Kutan A.M. 2008. Is PPP sensitive to time-varying trade weights in constructing real effective exchange rates?. The Quarterly Review of Economics and Finance 49, 3, 1001-1008.

[2] Baum C.F., Barkoulas J.T., Caglayan M. 1999. Long memory or structural breaks: can either explain nonstationary real exchange rates under the current float?. Journal of International Financial Markets, Institutions and Money 9, 359-376.

[3] Bec F., Ben Salem M., Carrasco M.. 2004. Tests for Unit-Root versus Threshold Specification With an Application to the Purchasing Power Parity Relationship. Journal of Business \& Economic Statistics 22, 382395.

[4] Bergman M.U., Hansson J. 2005. Real exchange rates and switching regimes. Journal of International Money and Finance 24, 121-138.

[5] Campbell J.Y., Mankiw N.G. 1987. Are output fluctuations transitory?. Quarterly Journal of Economics 102, 857-880.

[6] Caporale G.M., Cunado J., Gil-Alana L.A. 2007. Deterministic versus stochastic seasonal fractional integration and structural breaks. Brunel University, Discussion Paper.

[7] Caporale G.M., Gil-Alana L.A. 2007a. Mean reversion in the US treasury constant maturity rates. Centre for International Capital Markets, Discussion Paper No 2007-5.

[8] Caporale G.M., Gil-Alana L.A. 2007b. Mean reversion in the Nikkei, Standard \& Poor and Dow Jones stock market indices. Brunel University, Discussion Paper.

[9] Caporale G.M., Gil-Alana L.A. 2007c. Long-range forecasting in the S\&P stock market index using fractional integration techniques. Centre for International Capital Markets, Discussion Paper No 2007-4.

[10] Cerrato, M., Kim, H., MacDonald, R. (2010). 3-Regime asymmetric STAR modeling and exchange rate reversion. Journal of Money Credit and Banking, forthcoming. 
[11] Cheung Y.W., Lai K.S. 1993. A fractional cointegration analysis of purchasing power parity. Journal of Business and Economic Statistics $11,103-112$.

[12] Cheung Y.W., Lai K.S. 1998. Parity reversion in real exchange rates during the post-Bretton Woods period. Journal of International Money and Finance 17, 597-614.

[13] Cheung Y.W., Lai K.S. 2000. On the purchasing power parity puzzle. Journal of International Economics 52, 321-330.

[14] Cheung Y.W., Lai K.S. 2005. Nominal exchange rate flexibility and real exchange rate adjustment: evidence from dual exchange rates in developing countries. CESIFO Working Paper n 1512.

[15] Chortareas G., Kapetanios, G. 2004. How puzzling is the PPP puzzle? An alternative half-life measure of convergence to PPP. Working Papers 522, Queen Mary, University of London, School of Economics and Finance.

[16] Choudhry T., McNown R., Wallace M. 1991. Purchasing Power Parity and the Canadian float in the 1950s. Review of Economics and Statistics 73(3), 558-563.

[17] Chowdhuri A., Sdogati R. 1993. Purchasing Power Parity in the major EMS countries: the role of price and exchange rates adjustment. Journal of Macroeconomics 15, 25-45.

[18] Christopoulos D.K., Leon-Ledesma M.A. 2010. Smooth breaks and nonlinear mean reversion: Post-Bretton Woods real exchange rates. Journal of International Money and Finance 29, 1076-1093.

[19] Cunado J., Gil-Alana L.A., Perez de Gracia F. 2007. Testing for stock market bubbles using nonlinear models and fractional integration. Applied Financial Economics 17, 1313-1321.

[20] Diebold F.X, Inoue A. 2001. Long memory and regime switching. Journal of Econometrics 105, 131-159.

[21] Dornbusch R. 1976. Expectations and Exchange Rate Dynamics. Journal of Political Economy 84(6), 1161-76.

[22] Drine I., Rault, C. 2008. Purchasing power parity for developing and developed countries. What can we learn from nonstationary panel data models. Journal of Economic Surveys 22, 752-773. 
[23] Dufrénot G., Lardic S., Mathieu L., Mignon V., Péguin-Feissolle A. 2008. Explaining the European exchange rate deviations: long memory or nonlinear adjustment?. Journal of International Financial Markets, Institutions \& Money 18, 207-215.

[24] Dufrénot G., Mathieu L., Mignon V., Péguin-Feissolle A. 2006. Persistent misalignments of the European exchange rates: some evidence from nonlinear cointegration. Applied Economics 38, 203-229.

[25] Dumas B. 1992. Dynamic equilibrium and the real exchange rate in spatially separated world. Review of Financial Studies 5, 153-80.

[26] El-Gamal, M.A., Ryu D. 2006. Short-memory and the PPP hypothesis. Journal of Economic Dynamics and Control 30, 361-391.

[27] Engle R.F., Granger C.W.J. 1987. Cointegration and error-correction: representation, estimation, and testing. Econometrica 55, 251-276.

[28] Engel C., Morley J.C. 2001. The adjustment of prices and the adjustment of the exchange rate. NBER Working Paper no. 8550.

[29] Frenkel J. 1976. A Monetary Approach to the Exchange Rate: Doctrinal Aspects and Empirical Evidence. Scandinavian Journal of Economics $78,200-224$.

[30] Geweke J., Porter-Hudak S. 1983. The estimation and application of long memory time series models. Journal of Time Series Analysis 4 , 221-238.

[31] Gil-Alana L. A. 2000. Mean reversion in the real exchange rates. Economics Letters 69(3), 285-288.

[32] Gil-Alana L.A. 2008. Fractional integration and structural breaks at unknown periods of time. Journal of Time Series Analysis 29, 1, 163185.

[33] Gil-Alana L.A., Caporale G.M. 2006. Nonlinearities and fractional integration in the US unemployment rate. WP No 18/06, Universidad de Navarra, Spain.

[34] Gil-Alana L.A., Nazarski M. 2007. Strong dependence in the nominal exchange rates of the Polish zloty. Applied Stochastic Models in Business and Industry 23, 97-116. 
[35] Gil-Alana L.A., Toro J. 2002. Estimation and testing of ARFIMA models in the real exchange rate. International Journal of Finance and Economics 7, 279-298.

[36] Granger C.W.J, Hyung N. 2004. Occasional structural breaks and long memory with an application to the S\&P 500 absolute stock returns. Journal of Empirical Finance 11, 399-421.

[37] Granger C. W. J., Joyeux R. 1980. An introduction to long-memory time series models and fractional differencing. Journal of Time Series Analysis 1,15-29.

[38] Haubrich J.G., Lo A.W. 1989. The source and nature of long-term memory in the business cycles. Alfred P. Sloan School of Management Working Paper, ${ }^{\circ} 3062-89-E F A$.

[39] Holmes M.J. 2002. Purchasing power parity and the fractional integration of the real exchange rate: new evidence for less developed countries. Journal of Economic Development 27, 1, 125-135.

[40] Imbs J., Mumtaz H., Ravn M., Rey H. 2005. PPP strikes back: aggregation and the real exchange rate. The Quarterly Journal of Economics 120(1), 1-43.

[41] Kapetanios G., Shin Y., Snell A. 2003. Testing for a unit root in the nonlinear STAR framework. Journal of Econometrics 112, 2, 359-379.

[42] Kanas A. 2006. Purchasing power parity and Markov regime switching. Journal of Money, Credit and Banking 38, 1669-1687.

[43] Kilian L., Taylor M. P. 2003. Why is it so difficult to beat the random walk forecast of exchange rates?. Journal of International Economics $60,1,85-107$.

[44] Kiliç R. 2009. Further on nonlinearity, persistence, and integration properties of real exchange rates. Journal of International Financial Markets, Institutions and Money 19, 207-221.

[45] Kruse R., Frömmel M., Menkhoff L., Sibbertsen P. 2009. What do we know about real exchange rate non-linearities?. CREATES Research Papers 2009-50, School of Economics and Management, University of Aarhus. 
[46] Kwiatowski D., Phillips P.C.B., Schmidt P., Shin Y. 1992. Testing the null hypothesis of stationarity against the alternative of a unit root: how sure are we that economic time series have a unit root?. Journal of Econometrics 54, 159-178.

[47] Lee D., Schmidt P. 1996. On the power of KPSS test of stationarity against fractionally integrated alternatives. Journal of Econometrics 73, 285-302.

[48] McMillan D. 2009. The confusing time-series behavior of real exchange rates: Are asymmetries important?. Journal of International Financial Markets, Institutions and Money 19, 4, 692-711.

[49] Obstfeld M., Taylor A.M. 1997. Non-linear aspects of goods-market arbitrage and adjustment: Heckscher's commodity point revisited. Journal of Japanese and International Economics 11, 441-479.

[50] Park J.Y., Shintani M. 2005. Testing for a Unit Root against Transitional Autoregressive Models. Working Papers 05010, Department of Economics, Vanderbilt University.

[51] Perron P.. 1989. The Great Crash, the Oil Price Shock, and the Unit Root Hypothesis. Econometrica 57(6), 1361-1401.

[52] Perron P., Qu Z. 2004. An analytical evaluation of the log-periodogram estimate in the presence of level shifts and its implications for stock returns volatility. Working Paper, Boston University.

[53] Perron P., Qu Z. 2010. Long-memory and level shifts in the volatility of stock market return indices. Journal of Business \& Economic Statistics $28,2,275-290$.

[54] Robinson P.M. 1994. Efficient tests of nonstationary hypotheses. Journal of the American Statistical Association 89, 1420-1437.

[55] Robinson P.M. 1995. Log-periodogram regression of time series with long range dependence. Annals of Statistics 23, 1048-1072.

[56] Rogoff K.S. 1996. The Purchasing Power Parity Puzzle. Journal of Economic Literature 34, 647-68.

[57] Sarno L., Taylor M.P. 2001. Official Intervention in the Foreign Exchange Market: Is It Effective and, If So, How Does It Work?. Journal of Economic Literature 39, 3, 839-868. 
[58] Sercu P., Uppal R., Van Hulle C. 1995. The exchange rate in the presence of transactions costs: implications for tests of purchasing power parity. Journal of Finance 50, 1309-19.

[59] Shimotsu K. 2006. Exact local Whittle estimation of fractional integration with unknown mean and time trend. Working Paper N. 1061, Queen's University, Canada.

[60] Shimotsu K., Phillips P.C.B. 2004. Local Whittle estimation in nonstationary and unit root cases. Annals of Statistics 32, 2, 656-692.

[61] Shimotsu K., Phillips P.C.B. 2005. Exact local Whittle estimation of fractional integration. Annals of Statistics 33, 4, 1890-1933.

[62] Shimotsu K., Phillips P.C.B. 2006. Local Whittle estimation of fractional integration and some of its variants. Journal of Econometrics 130, 209-233.

[63] Smith A. 2005. Level shifts and the illusion of long memory in economic time series. Journal of Business and Economic Statistics 23, 3, 321-335.

[64] Sollis R. 2008. U.S. dollar exchange rates: nonlinearity revisited. Journal of International Money and Finance 27, 516-528.

[65] Taylor A.M. 2001. Potential Pitfalls for the Purchasing-Power-ParityPuzzle? Sampling and Specification Biases in Mean-Reversion Tests of the Law of One Price. Econometrica 69. 473-498.

[66] Taylor M.P. 2003. Purchasing Power Parity. Review of International Economics 11, 3, 436-452.

[67] Taylor, M.P. 2006. Real exchange rates and Purchasing Power Parity: mean-reversion in economic thought. Applied Financial Economics 16, $1-17$.

[68] Taylor M.P., Peel D.A., Sarno L. 2001. Nonlinear mean-reversion in real exchange rates: towards a solution to the purchasing parity puzzles. International Economic Review 42, 1015-42.

[69] Taylor A.M., Taylor M.P. 2004. The purchasing power parity debate. NBER Working Paper No. 10607.

[70] Villeneuve J.-F., Handa J. 2006. Purchasing Power Parity as a longterm memory process: Evidence from Canada. Applied Financial Economics 16, 109-117. 


\section{Appendix 1: The Robinson (1994)'s LM statistic}

The Lagrange Multiplier (LM) statistic proposed by Robinson (1994), $\widehat{r}$, is given by:

$$
\widehat{r}=\left(\frac{T}{\widehat{A}}\right)^{1 / 2} \frac{\widehat{a}}{\widehat{\sigma}^{2}}
$$

where $T$ is the sample size and

$$
\begin{gathered}
\widehat{a}=\frac{-2 \pi}{T} \sum_{j=1}^{T-1} \psi\left(\lambda_{j}\right) g\left(\lambda_{j}, \widehat{\tau}\right)^{-1} I\left(\lambda_{j}\right) \\
\widehat{\sigma}^{2}=\frac{2 \pi}{T} \sum_{j=1}^{T-1} g\left(\lambda_{j}, \widehat{\tau}\right)^{-1} I\left(\lambda_{j}\right), \\
\widehat{A}=\frac{2}{T}\left[\sum_{j=1}^{T-1} \psi\left(\lambda_{j}\right)^{2}-\sum_{j=1}^{T-1} \psi\left(\lambda_{j}\right) \widehat{\varepsilon}\left(\lambda_{j}\right)^{\prime}\right. \\
\left.\times\left(\sum_{j=1}^{T-1} \widehat{\varepsilon}\left(\lambda_{j}\right) \widehat{\varepsilon}\left(\lambda_{j}\right)^{\prime}\right)^{-1} \sum_{j=1}^{T-1} \widehat{\varepsilon}\left(\lambda_{j}\right) \psi\left(\lambda_{j}\right)\right] \\
\widehat{\tau}=\underset{\tau \in T^{*}}{\arg \min } \widehat{\sigma}^{2}, \quad \psi\left(\lambda_{j}\right)=\log \left|2 \sin \frac{\lambda_{j}}{2}\right|, \quad \lambda_{j}=\frac{2 \pi j}{T} \\
\widehat{\varepsilon}\left(\lambda_{j}\right)=\frac{\partial}{\partial \tau} \log g\left(\lambda_{j}, \widehat{\tau}\right), \quad g(\lambda, \tau)=\frac{2 \pi}{\sigma^{2}} f\left(\lambda, \tau, \sigma^{2}\right) ;
\end{gathered}
$$

$f$ is the spectral density of $u_{t}, T^{*}$ is a suitable set of $R^{k}$ and $I\left(\lambda_{j}\right)$ is the periodogram of

$$
\widehat{u}_{t}=(1-L)^{d} y_{t}-\widehat{\beta}^{\prime} w_{t}
$$

evaluated at $\lambda_{j}$ with

$$
w_{t}=(1-L)^{d} z_{t}
$$

and

$$
\widehat{\beta}=\left(\sum_{t=1}^{T} w_{t} w_{t}^{\prime}\right)^{-1} \sum_{t=1}^{T} w_{t}(1-L)^{d} y_{t} .
$$

Note that $\sigma^{2}$ is generally no longer the variance of $u_{t}$, but rather the variance of the innovation sequence in a normalized Wold representation of $u_{t}$. 


\section{Appendix 2: List of countries}

$\begin{array}{llll}\text { Algeria } & \text { El Salvador } & \text { Kenya } & \text { Samoa } \\ \text { Argentina } & \text { Ethiopia } & \text { Korea } & \text { Senegal } \\ \text { Australia } & \text { Fiji } & \text { Luxembourg } & \text { Singapore } \\ \text { Austria } & \text { Finland } & \text { Madagascar } & \text { South Africa } \\ \text { Belgium } & \text { France } & \text { Malaysia } & \text { Spain } \\ \text { Bolivia } & \text { Gambia } & \text { Malta } & \text { Sri Lanka } \\ \text { Brazil } & \text { Germany } & \text { Mauritius } & \text { St. Lucia } \\ \text { Cameroon } & \text { Ghana } & \text { Mexico } & \text { Swaziland } \\ \text { Canada } & \text { Greece } & \text { Morocco } & \text { Sweden } \\ \text { Chile } & \text { Guatemala } & \text { Nepal } & \text { Switzerland } \\ \text { China, PR } & \text { Haiti } & \text { Netherlands } & \text { Taiwan } \\ \text { Colombia } & \text { Honduras } & \text { New Zealand } & \text { Thailand } \\ \text { Congo } & \text { Hong Kong } & \text { Niger } & \text { Trinidad Tobago } \\ \text { Costa Rica } & \text { Hungary } & \text { Nigeria } & \text { Tunisia } \\ \text { Ivory Coast } & \text { India } & \text { Norway } & \text { Turkey } \\ \text { Cyprus } & \text { Indonesia } & \text { Pakistan } & \text { U.K. } \\ \text { Denmark } & \text { Israel } & \text { Paraguay } & \text { Uruguay } \\ \text { Dominican R. } & \text { Italy } & \text { Peru } & \text { Venezuela } \\ \text { Ecuador } & \text { Jamaica } & \text { Philippines } & \\ \text { Egypt } & \text { Japan } & \text { Portugal } & \end{array}$


Table 1. Second step: the KPSS test (Real exchange rates in log)

\begin{tabular}{l|l|r|r|r|r}
$\begin{array}{l}\text { with respect } \\
\text { to US\$ }\end{array}$ & \multicolumn{2}{|l|}{$\begin{array}{l}S_{t} \\
\widehat{\eta}_{\mu}(6)\end{array}$} & $\widehat{\eta}_{\mu}(12)$ & \multicolumn{1}{l}{$\widehat{\widehat{\eta}}_{\mu}(6)$} & $\widehat{\eta}_{\mu}(12)$ \\
\hline \hline South and & Bolivia & 3.77 & 2.25 & 0.01 & 0.03 \\
Latin America & Brazil & 4.18 & 2.31 & 0.03 & 0.04 \\
& Costa Rica & 4.02 & 2.23 & 0.06 & 0.06 \\
& El Salvador & 5.70 & 3.15 & 0.02 & 0.03 \\
& Mexico & 0.59 & 0.34 & 0.03 & 0.03 \\
& Peru & 4.12 & 2.26 & 0.05 & 0.07 \\
& Venezuela & 2.18 & 1.24 & 0.04 & 0.05 \\
\hline Africa & Congo DR. & 3.77 & 2.12 & 0.05 & 0.08
\end{tabular}

\begin{tabular}{|c|c|c|c|c|c|}
\hline \multicolumn{2}{|l|}{$\begin{array}{l}\text { with respect } \\
\text { to UK£ }\end{array}$} & \multirow{2}{*}{$\begin{array}{l}S_{t} \\
\widehat{\eta}_{\mu}(6) \\
4.65\end{array}$} & \multirow{2}{*}{$\begin{aligned} \widehat{\eta}_{\mu}(12) \\
2.60\end{aligned}$} & \multirow{2}{*}{$\begin{array}{c}\Delta S_{t} \\
\widehat{\eta}_{\mu}(6) \\
0.03\end{array}$} & \multirow{2}{*}{$\begin{array}{r}\widehat{\eta}_{\mu}(12) \\
0.03\end{array}$} \\
\hline 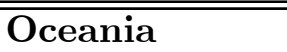 & Australia & & & & \\
\hline & New Zealand & 1.95 & 1.11 & 0.03 & 0.04 \\
\hline \multirow[t]{2}{*}{ Europe } & Malta & 5.48 & 3.01 & 0.08 & 0.10 \\
\hline & Turkey & 3.58 & 1.99 & 0.06 & 0.08 \\
\hline South and & Bolivia & 4.79 & 2.35 & 0.01 & 0.02 \\
\hline \multirow[t]{5}{*}{ Latin America } & Brazil & 4.91 & 2.73 & 0.01 & 0.02 \\
\hline & Costa Rica & 4.39 & 2.44 & 0.05 & 0.05 \\
\hline & Mexico & 1.33 & 0.78 & 0.03 & 0.03 \\
\hline & Peru & 3.59 & 1.99 & 0.05 & 0.08 \\
\hline & Venezuela & 2.78 & 1.56 & 0.04 & 0.05 \\
\hline \multirow[t]{4}{*}{ Africa } & Tunisia & 5.20 & 2.86 & 0.10 & 0.12 \\
\hline & Congo DR. & 4.16 & 2.33 & 0.04 & 0.06 \\
\hline & Ivory Coast & 3.93 & 2.18 & 0.05 & 0.06 \\
\hline & Swaziland & 4.84 & 2.69 & 0.04 & 0.04 \\
\hline Asia & Nepal & 5.73 & 3.13 & 0.08 & 0.09 \\
\hline
\end{tabular}




\begin{tabular}{l|l|r|r|r|r}
\multicolumn{2}{l|}{$\begin{array}{l}\text { with respect } \\
\text { to German DM }\end{array}$} & \multicolumn{1}{l|}{$S_{t}$} & \multicolumn{1}{l}{$\Delta S_{t}$} \\
\hline Oceania & New Zealand & 0.32 & 0.19 & 0.02 & 0.02 \\
\hline \hline Europe & Austria & 5.15 & 2.82 & 0.10 & 0.15 \\
& Belgium & 0.88 & 0.52 & 0.02 & 0.03 \\
& Denmark & 4.46 & 2.50 & 0.02 & 0.02 \\
& France & 0.48 & 0.30 & 0.02 & 0.02 \\
& Greece & 3.26 & 1.87 & 0.16 & 0.21 \\
& Luxembourg & 2.38 & 1.38 & 0.05 & 0.08 \\
& Netherlands & 1.21 & 0.68 & 0.04 & 0.07 \\
& Switzerland & 4.50 & 2.51 & 0.15 & 0.19 \\
& Turkey & 2.27 & 1.28 & 0.09 & 0.11 \\
\hline South and & Bolivia & 2.38 & 1.42 & 0.01 & 0.02 \\
Latin America & Brazil & 4.55 & 2.57 & 0.01 & 0.02 \\
& Costa Rica & 3.60 & 2.03 & 0.10 & 0.10 \\
& Peru & 4.62 & 2.55 & 0.06 & 0.09 \\
\hline Africa & Congo DR. & 3.61 & 2.04 & 0.04 & 0.06 \\
& South Africa & 4.17 & 2.35 & 0.03 & 0.03
\end{tabular}

Note: $S_{t}$ is the real exchange rate in log. $\widehat{\eta}_{\mu}(l)$ is the $\widehat{\eta}_{\mu}$ statistic of Kwiatowski et al.(1992) where $l$ is the truncation parameter used in estimating the long run variance (see Kwiatowski et al.(1992) page 165); the critical values are: $0.347(10 \%), 0.463(5 \%)$ and $0.739(1 \%)$. 
Table 2. Third step: the KSS test (Real exchange rates in log)

\begin{tabular}{|c|c|c|c|c|c|}
\hline \multicolumn{2}{|l|}{$\begin{array}{l}\text { with respect } \\
\text { to US } \$\end{array}$} & $S_{t}$ & \multicolumn{2}{|l|}{$\begin{array}{l}\text { with respect } \\
\text { to } \mathrm{UK£}\end{array}$} & \multirow{3}{*}{$\begin{array}{l}S_{t} \\
-3.82 \\
-3.25\end{array}$} \\
\hline South and & Bolivia & $\begin{array}{l}-13.08 \\
\end{array}$ & \multirow[t]{2}{*}{ Oceania } & Australia & \\
\hline \multirow[t]{5}{*}{ Latin America } & Brazil & -4.42 & & New Zealand & \\
\hline & Costa Rica & -5.66 & \multirow[t]{2}{*}{ Europe } & Malta & -1.32 \\
\hline & El Salvador & -1.33 & & Turkey & -2.57 \\
\hline & Peru & -1.88 & \multirow{6}{*}{$\begin{array}{l}\text { South and } \\
\text { Latin America }\end{array}$} & Bolivia & -12.45 \\
\hline & Venezuela & -3.06 & & Brazil & -2.27 \\
\hline \multirow[t]{9}{*}{ Africa } & \multirow[t]{9}{*}{ Congo DR. } & \multirow[t]{9}{*}{-1.98} & & Costa Rica & -2.79 \\
\hline & & & & Mexico & -3.91 \\
\hline & & & & Peru & -2.10 \\
\hline & & & & Venezuela & -3.04 \\
\hline & & & Africa & Tunisia & -0.77 \\
\hline & & & & Congo DR. & -1.88 \\
\hline & & & & Ivory Coast & -1.72 \\
\hline & & & & Swaziland & -2.22 \\
\hline & & & Asia & Nepal & -1.83 \\
\hline \multirow{2}{*}{\multicolumn{2}{|c|}{$\begin{array}{l}\text { with respect } \\
\text { to German DM }\end{array}$}} & & & & \\
\hline & & $S_{t}$ & & & \\
\hline \multirow[t]{6}{*}{ Europe } & Austria & -1.34 & & & \\
\hline & Denmark & -1.33 & & & \\
\hline & Greece & -1.62 & & & \\
\hline & Luxembourg & -3.22 & & & \\
\hline & Switzerland & -1.57 & & & \\
\hline & Turkey & -3.64 & & & \\
\hline South and & Bolivia & -11.62 & & & \\
\hline \multirow[t]{3}{*}{ Latin America } & Brazil & -4.64 & & & \\
\hline & Costa Rica & -5.06 & & & \\
\hline & Peru & -1.79 & & & \\
\hline \multirow[t]{2}{*}{ Africa } & Congo DR. & -3.17 & & & \\
\hline & South Africa & -2.79 & & & \\
\hline
\end{tabular}

Note: $S_{t}$ is the real exchange rate in log. $K S S$ is the augmented Kapetanios, Shin and Snell (2003) test performed using demeaned data; the critical values are: $-2.66(10 \%),-2.93(5 \%),-3.48(1 \%)$. 
Table 3. Third step: the Perron and Qu (2004 and 2010) test

\begin{tabular}{|c|c|c|c|c|c|}
\hline \multicolumn{2}{|l|}{$\begin{array}{l}\text { with respect } \\
\text { to US\$ }\end{array}$} & \multirow{2}{*}{ 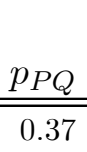 } & \multicolumn{2}{|l|}{$\begin{array}{l}\text { with respect } \\
\text { to } \mathrm{UK} £\end{array}$} & \multirow{3}{*}{$\begin{array}{r}p_{P Q} \\
0.67 \\
0.63\end{array}$} \\
\hline South and & Bolivia & & \multirow[t]{2}{*}{ Oceania } & Australia & \\
\hline \multirow[t]{5}{*}{ Latin America } & Brazil & 0.00 & & New Zealand & \\
\hline & Costa Rica & 0.87 & \multirow[t]{2}{*}{ Europe } & Malta & 0.02 \\
\hline & El Salvador & 0.63 & & Turkey & 0.94 \\
\hline & Peru & 0.16 & \multirow{6}{*}{$\begin{array}{l}\text { South and } \\
\text { Latin America }\end{array}$} & Bolivia & 0.40 \\
\hline & Venezuela & 0.77 & & Brazil & 0.16 \\
\hline \multirow[t]{9}{*}{ Africa } & \multirow[t]{9}{*}{ Congo DR. } & \multirow[t]{9}{*}{0.83} & & Costa Rica & 0.42 \\
\hline & & & & Mexico & 0.09 \\
\hline & & & & Peru & 0.38 \\
\hline & & & & Venezuela & 0.29 \\
\hline & & & Africa & Tunisia & 0.04 \\
\hline & & & & Congo DR. & 0.45 \\
\hline & & & & Ivory Coast & 0.66 \\
\hline & & & & Swaziland & 0.53 \\
\hline & & & Asia & Nepal & 0.36 \\
\hline \multirow{2}{*}{\multicolumn{2}{|c|}{$\begin{array}{l}\text { with respect } \\
\text { to German DM }\end{array}$}} & & & & \\
\hline & & $p_{P Q}$ & & & \\
\hline \multirow[t]{6}{*}{ Europe } & Austria & 0.17 & & & \\
\hline & Denmark & 0.39 & & & \\
\hline & Greece & 0.11 & & & \\
\hline & Luxembourg & 0.84 & & & \\
\hline & Switzerland & 0.16 & & & \\
\hline & Turkey & 0.38 & & & \\
\hline South and & Bolivia & 0.43 & & & \\
\hline \multirow[t]{3}{*}{ Latin America } & Brazil & 0.08 & & & \\
\hline & Costa Rica & 0.43 & & & \\
\hline & Peru & 0.36 & & & \\
\hline \multirow[t]{2}{*}{ Africa } & Congo DR. & 0.65 & & & \\
\hline & South Africa & 0.50 & & & \\
\hline
\end{tabular}

Note: $p_{P Q}$ is the p-value of the Perron and $\mathrm{Qu}(2004$ and 2010) test. 
Table 4. Results for fractional integration

\begin{tabular}{|c|c|c|c|c|c|}
\hline \multicolumn{2}{|l|}{$\begin{array}{l}\text { with respect } \\
\text { to US\$ }\end{array}$} & \multirow{2}{*}{ 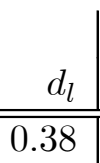 } & \multirow{2}{*}{$\frac{\widehat{d}_{w}}{\overline{0.52}}$} & \multirow{2}{*}{$\begin{array}{r}d_{u} \\
0.66\end{array}$} & $d_{R}$ \\
\hline South and & Bolivia & & & & 0.62 \\
\hline \multirow[t]{6}{*}{ Latin America } & Brazil & 0.59 & 0.73 & 0.87 & 0.62 \\
\hline & Costa Rica & 0.67 & 0.81 & 0.94 & 0.87 \\
\hline & El Salvador & 0.64 & 0.78 & 0.91 & 0.95 \\
\hline & Mexico & 0.66 & 0.80 & 0.93 & 0.92 \\
\hline & Peru & 0.61 & 0.75 & 0.88 & 0.82 \\
\hline & Venezuela & 0.67 & 0.81 & 0.94 & 0.82 \\
\hline Africa & Congo DR. & 0.70 & 0.84 & 0.98 & 0.77 \\
\hline \multirow{2}{*}{\multicolumn{2}{|c|}{$\begin{array}{l}\text { with respect } \\
\text { to } U K £\end{array}$}} & & & & \\
\hline & & $d_{l}$ & $\widehat{d}_{w}$ & $d_{u}$ & $d_{R}$ \\
\hline \multirow[t]{2}{*}{ Oceania } & Australia & 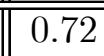 & 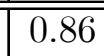 & 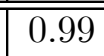 & 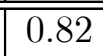 \\
\hline & New Zealand & 0.68 & 0.82 & 0.95 & 0.75 \\
\hline \multirow[t]{2}{*}{ Europe } & Malta & 0.72 & 0.85 & 0.99 & 0.97 \\
\hline & Turkey & 0.69 & 0.83 & 0.97 & 0.87 \\
\hline South and & Bolivia & 0.50 & 0.64 & 0.78 & 0.67 \\
\hline \multirow[t]{5}{*}{ Latin America } & Brazil & 0.57 & 0.70 & 0.84 & 0.62 \\
\hline & Costa Rica & 0.65 & 0.79 & 0.93 & 0.87 \\
\hline & Mexico & 0.67 & 0.80 & 0.94 & 0.95 \\
\hline & Peru & 0.55 & 0.69 & 0.83 & 0.85 \\
\hline & Venezuela & 0.70 & 0.84 & 0.98 & 0.85 \\
\hline \multirow[t]{4}{*}{ Africa } & Tunisia & 0.71 & 0.85 & 0.99 & 0.77 \\
\hline & Congo DR. & 0.69 & 0.83 & 0.97 & 0.77 \\
\hline & Ivory Coast & 0.72 & 0.86 & 0.99 & 0.92 \\
\hline & Swaziland & 0.68 & 0.82 & 0.96 & 0.95 \\
\hline Asia & Nepal & 0.72 & 0.86 & 0.99 & 0.92 \\
\hline
\end{tabular}




\begin{tabular}{l|l||r|r|r||c}
\multicolumn{2}{ll}{\begin{tabular}{l|r} 
with respect to \\
German DM
\end{tabular}} & $d_{l}$ & $\widehat{d}_{w}$ & $d_{u}$ & $d_{R}$ \\
\hline \hline Oceania & New Zealand & 0.65 & 0.79 & 0.92 & 0.77 \\
\hline Europe & Austria & 0.60 & 0.74 & 0.88 & 0.50 \\
& Belgium & 0.69 & 0.83 & 0.97 & 0.60 \\
& Denmark & 0.60 & 0.74 & 0.87 & 0.52 \\
& France & 0.70 & 0.84 & 0.97 & 0.65 \\
& Greece & 0.66 & 0.80 & 0.94 & 0.82 \\
& Luxembourg & 0.59 & 0.73 & 0.87 & 0.57 \\
& Netherlands & 0.56 & 0.70 & 0.84 & 0.47 \\
& Switzerland & 0.59 & 0.72 & 0.86 & 0.67 \\
& Turkey & 0.71 & 0.85 & 0.99 & 0.87 \\
\hline South and & Bolivia & 0.51 & 0.64 & 0.78 & 0.72 \\
Latin America & Brazil & 0.56 & 0.69 & 0.83 & 0.62 \\
& Costa Rica & 0.62 & 0.76 & 0.89 & 0.87 \\
& Peru & 0.58 & 0.71 & 0.85 & 0.85 \\
\hline Africa & Congo DR. & 0.69 & 0.82 & 0.96 & 0.77 \\
& South Africa & 0.62 & 0.76 & 0.90 & 0.95
\end{tabular}

Note: $\widehat{d}_{w}$ is the FELW estimator developed by Shimotsu (2006) of the long memory parameter; $d_{l}$ and $d_{u}$ are the lower and upper bounds of the $95 \%$ confidence intervals ( $m$ is chosen to be $m=T^{0.65}$ with $T$ is the sample size and the lower and upper bounds on the long memory parameter are respectively -0.2 and 1.4). $d_{R}$ is the value of the long memory parameter $d$ corresponding to the absolute value of the minimum of the Robinson (1994) test statistic. 
Table 5. Half-life estimates of bilateral exchange rates (in month)

\begin{tabular}{lrlll}
$\begin{array}{l}\text { with respect } \\
\text { to US } \$\end{array}$ & & & $\begin{array}{l}\text { with respect } \\
\text { to UK£ }\end{array}$ \\
\hline \hline Bolivia & 1.21 & & Australia & 69.68 \\
Costa Rica & 18.11 & & New Zealand & 24.06 \\
El Salvador & 10.48 & & Turkey & 30.25 \\
Mexico & 14.56 & & Ivory Coast & 69.68 \\
Peru & 6.73 & & Swaziland & 24.18 \\
Venezuela & 17.73 & & Nepal & 75.03
\end{tabular}

with respect to

German DM

\begin{tabular}{lr}
\hline \hline Austria & 6.40 \\
Belgium & 31.06 \\
Denmark & 5.94 \\
Greece & 15.03 \\
Luxembourg & 5.43 \\
Netherlands & 4.06 \\
Switzerland & 5.11
\end{tabular}

Note: The half-life is estimated by using a linear interpolation as follows: if $k$ is such that $I R F[k] \geq 0.5 \geq I R F[k+1]$ then the linear approximation for the half-life estimate is given by

$$
h=(0.5-(k+1) I R F[k]+k I R F[k+1]) /(\operatorname{IRF}[k+1]-I R F[k]) \text {. }
$$


Diagram 1. The testing strategy

$\left({ }^{*} \mathrm{~d}_{\mathrm{u}}\right.$ : the upper bound of the $95 \%$ confidence interval corresponding to the FELW estimator developed by Shimotsu (2006), LM : long memory, SM : short memory)

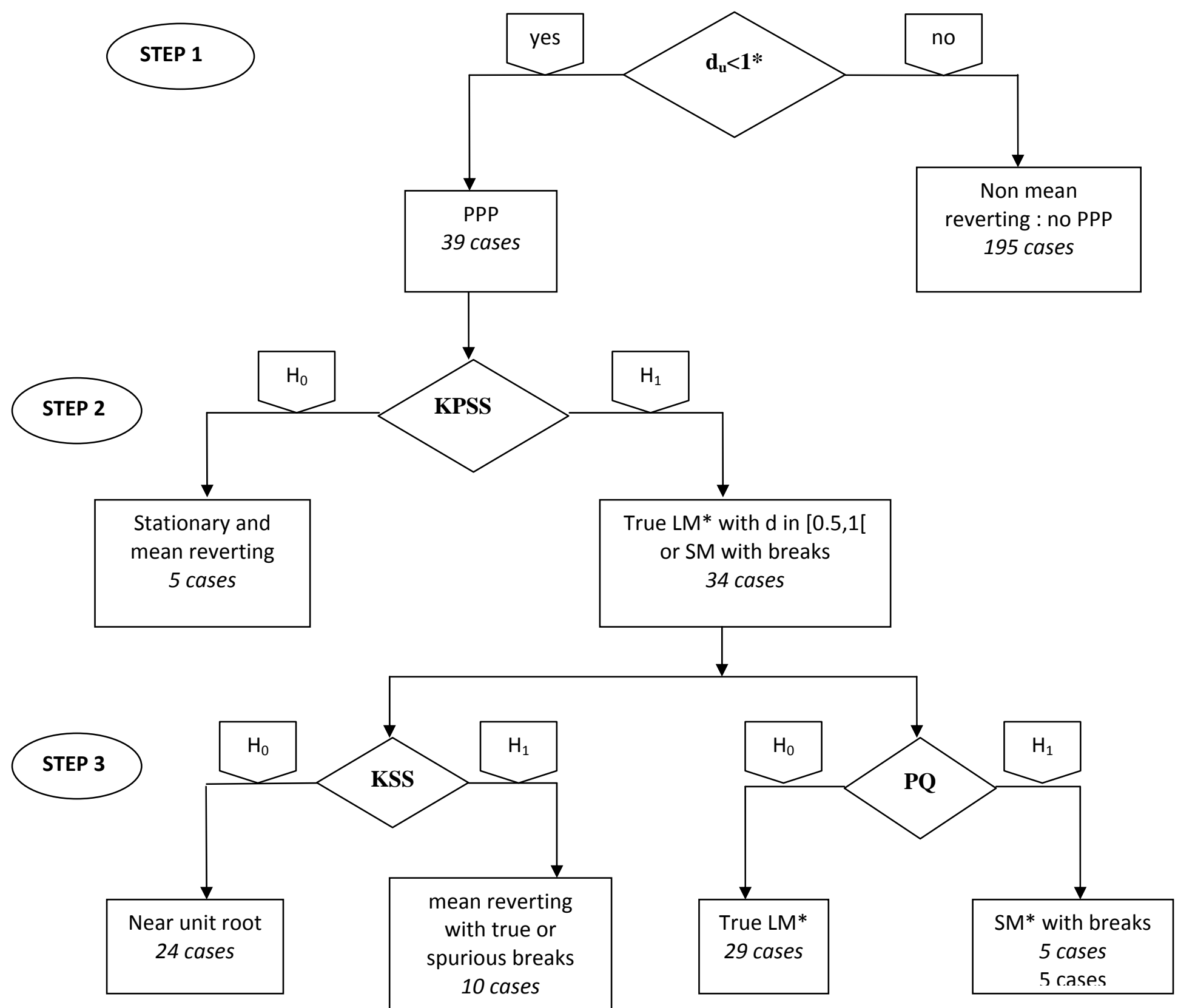


Figure 1. Perron-Qu test significance levels and d-sup estimates of bilateral real exchange rates with respect to USA

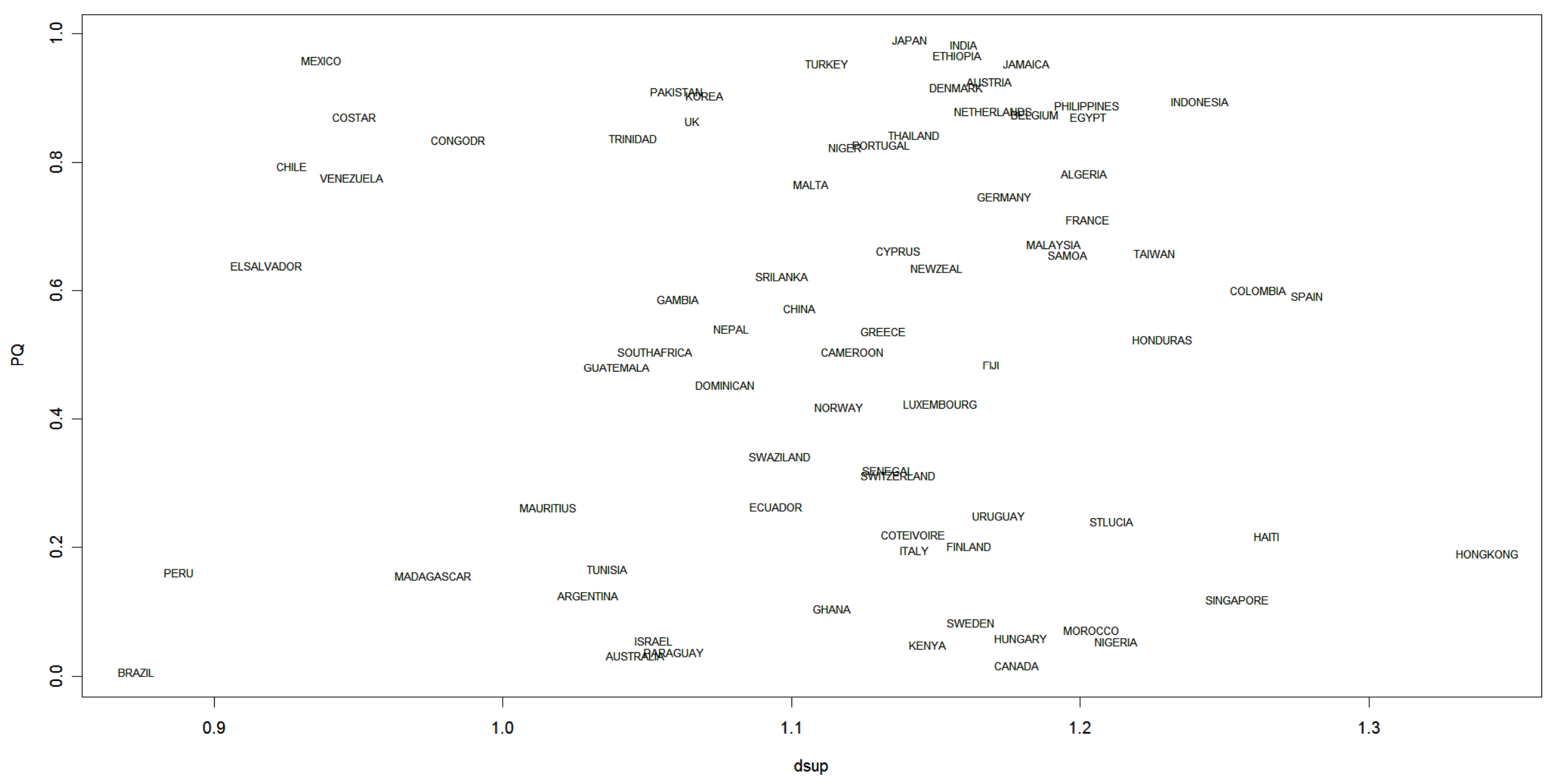

$P Q$ : $p$-value of the Perron and Qu test

dsup: upper bound of the $95 \%$ interval on the long memory parameter (FELW estimator)

Omitted values: Bolivia: dsup $=0.664 \mathrm{PQ}=0.3769$ 
Figure 2. Perron-Qu test significance levels and d-sup estimates of bilateral real exchange rates with respect to UK

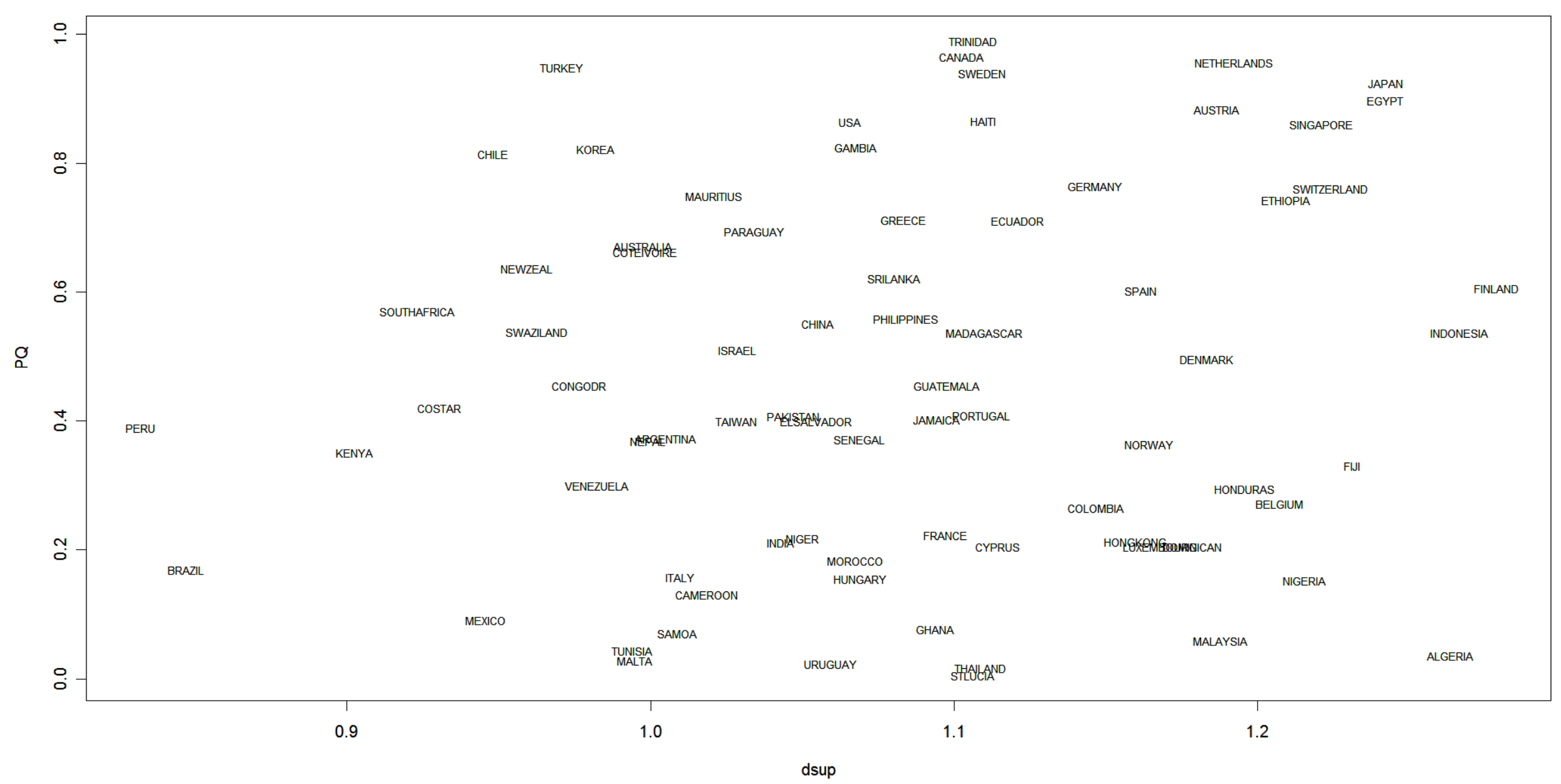

PQ : $p$-value of the Perron and Qu test

dsup: upper bound of the $95 \%$ interval on the long memory parameter (FELW estimator)

Omitted values: Bolivia: dsup $=0.7847$

$P Q=0.4341$ 
Figure 3. Perron-Qu test significance levels and d-sup estimates of bilateral real exchange rates with respect to Germany

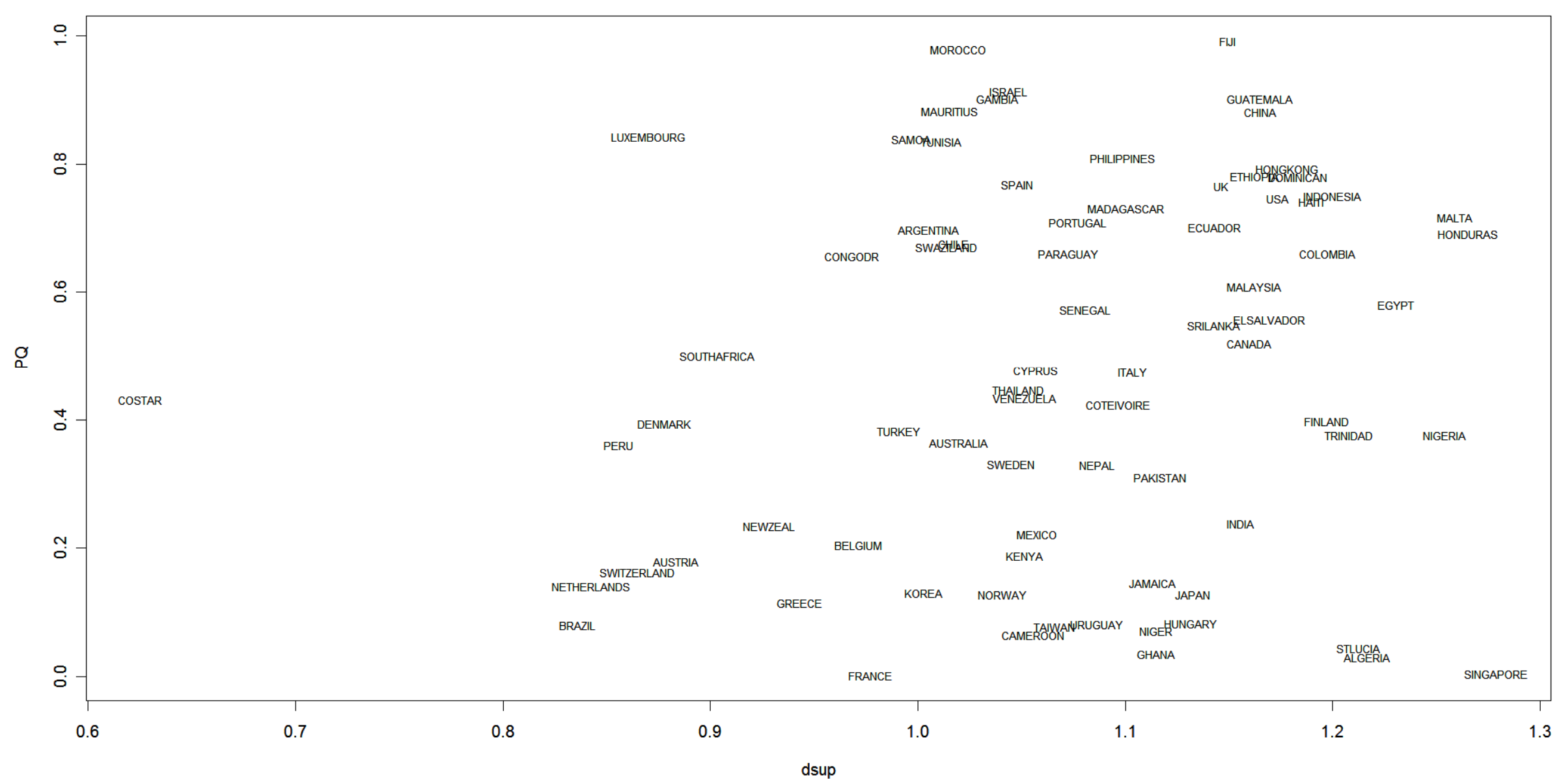

$P Q$ : $p$-value of the Perron and Qu test

dsup: upper bound of the $95 \%$ interval on the long memory parameter (FELW estimator)

Omitted values: Bolivia: dsup $=0.7816 \mathrm{PQ}=0.4093$ 
Figure 4. The impulse response function of bilateral exchange rates with respect to USA
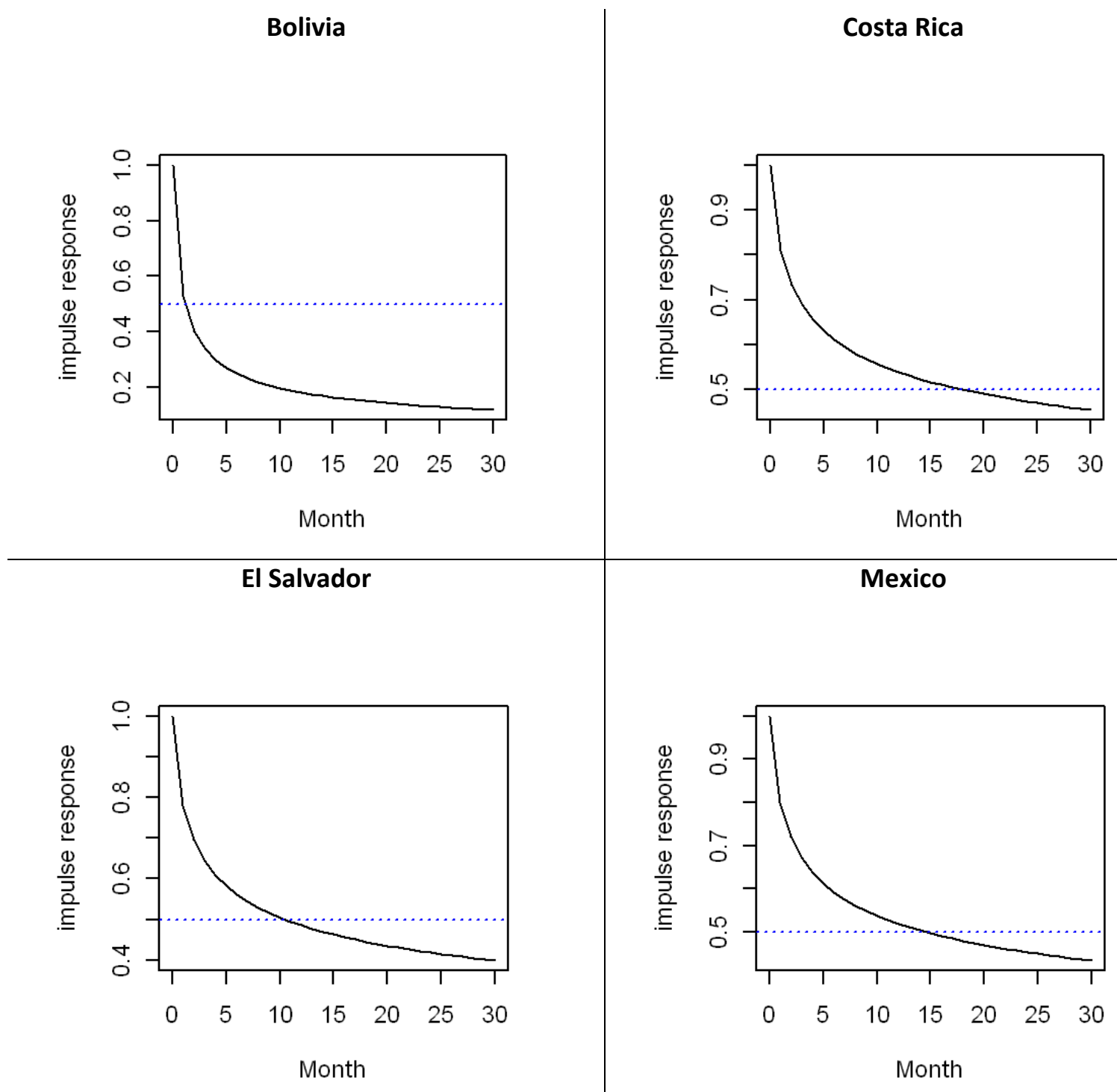

Mexico
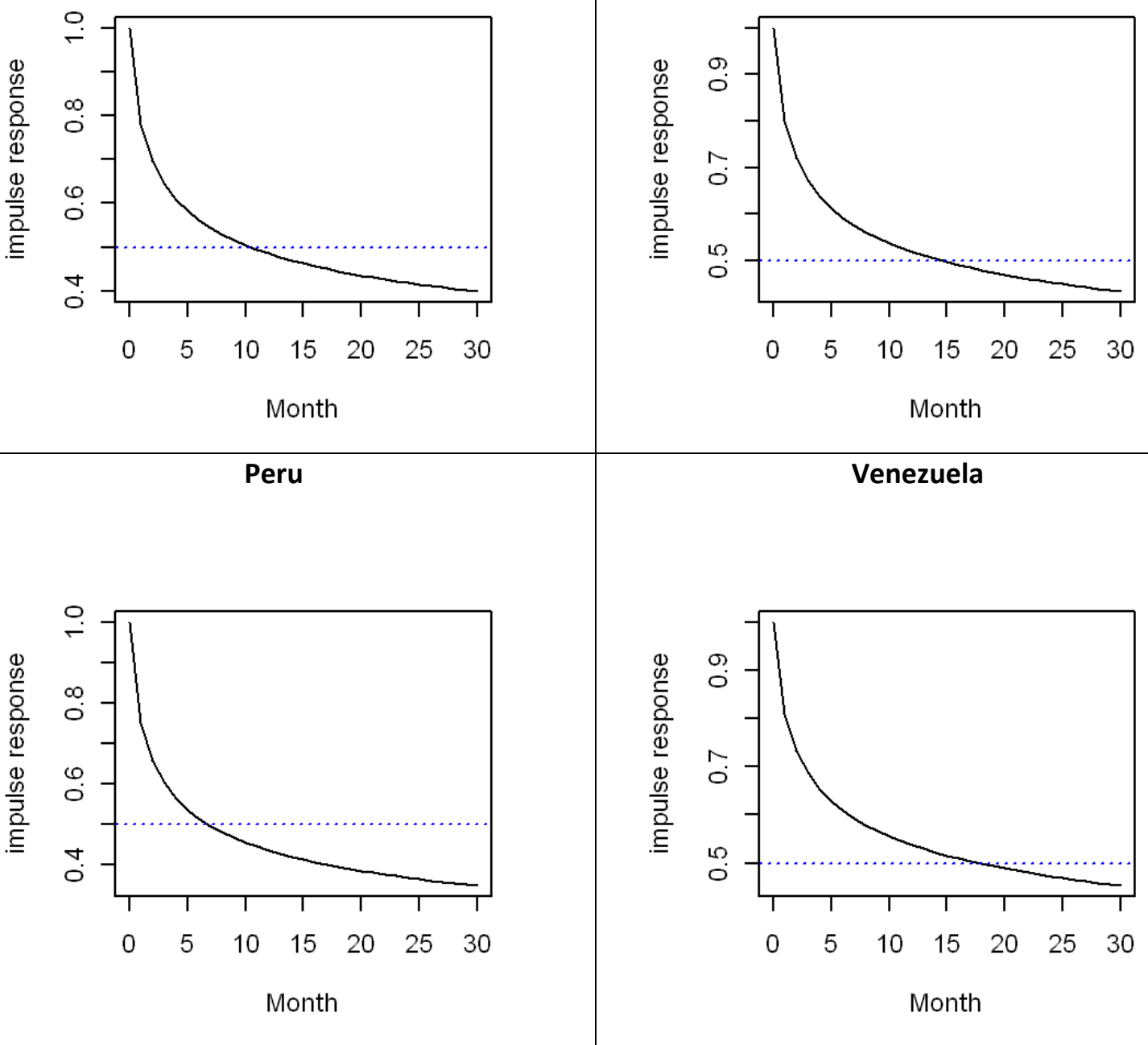
Figure 5. The impulse response function of bilateral exchange rates with respect to UK
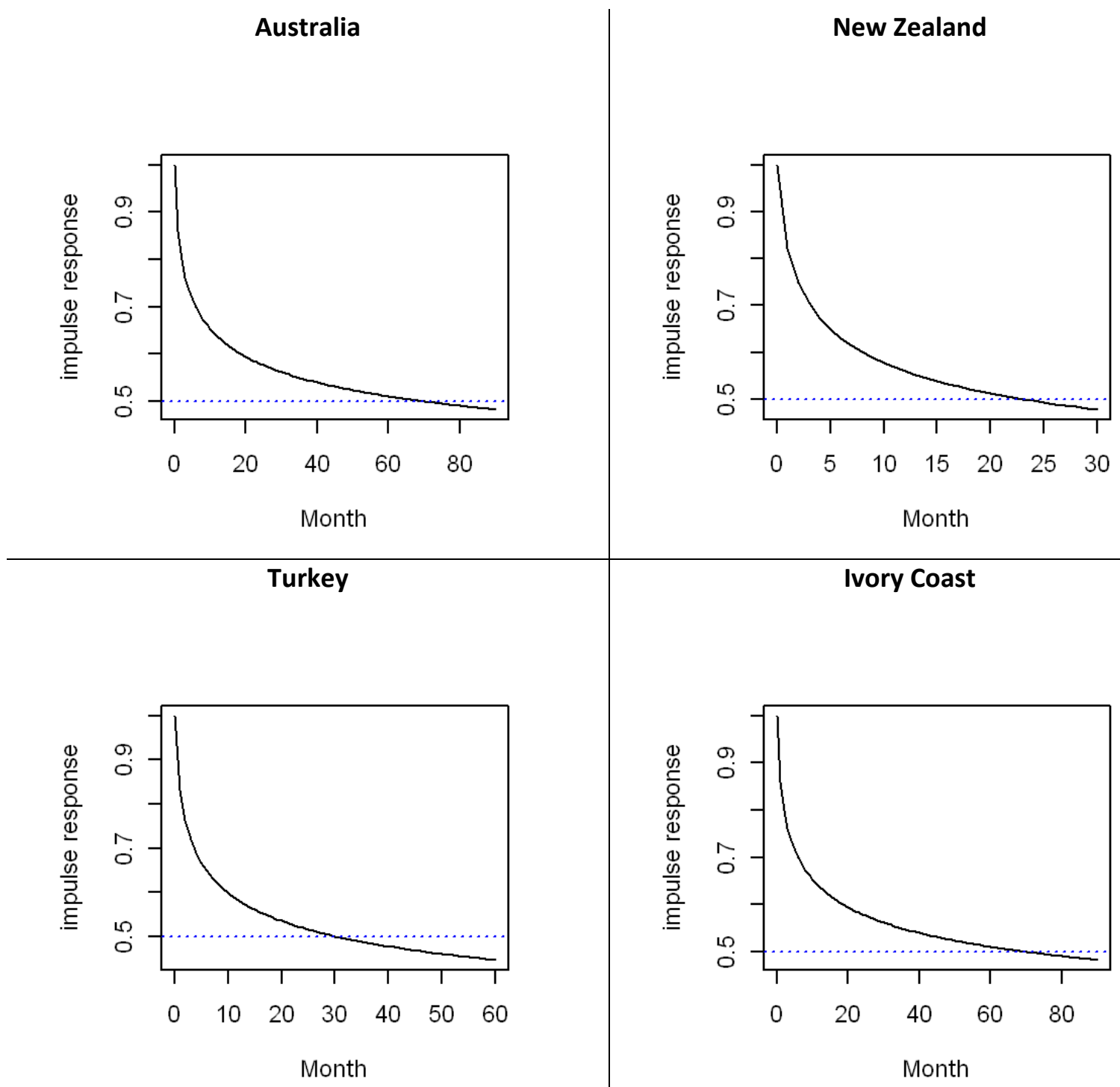

Ivory Coast
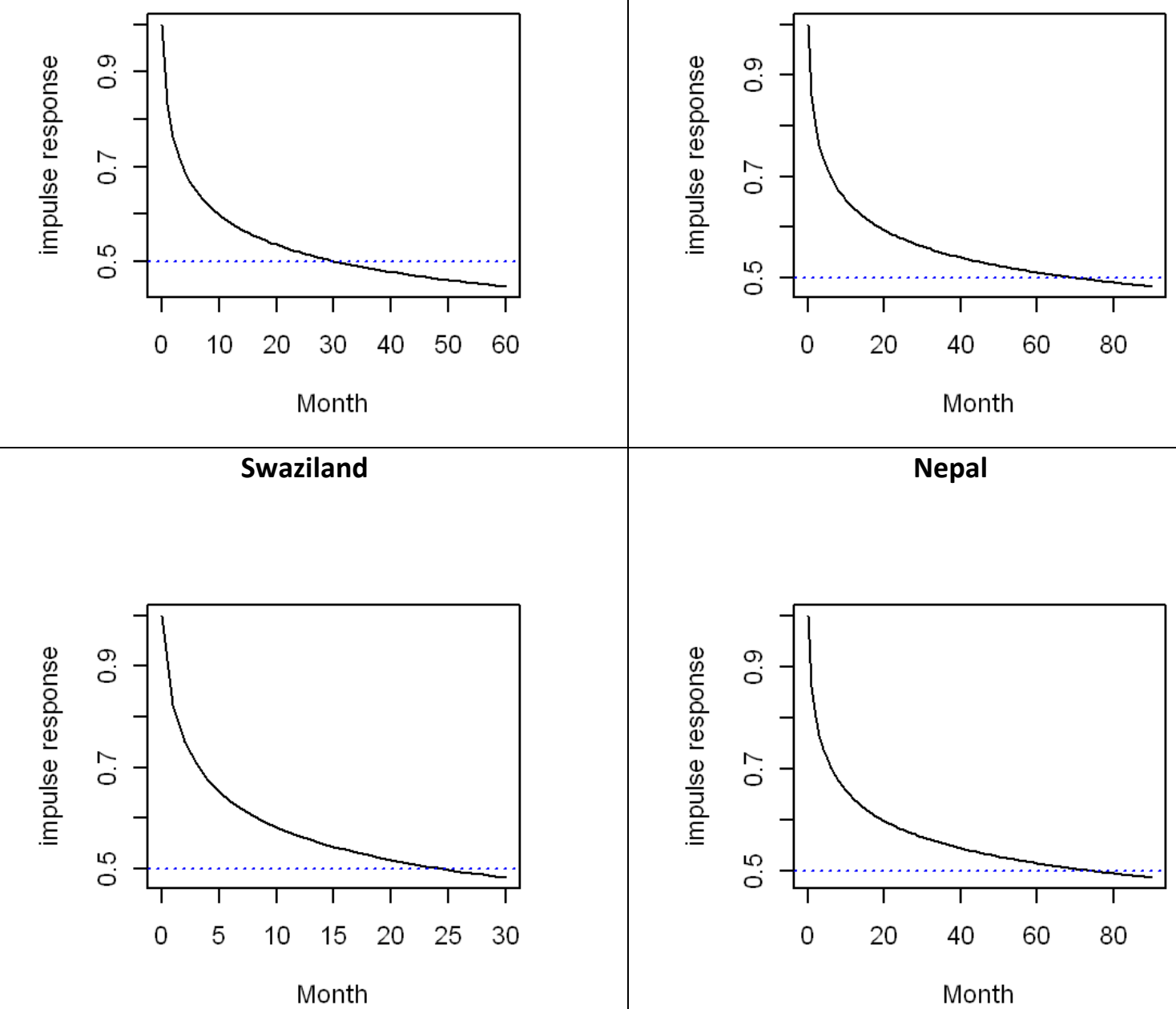

Nepal

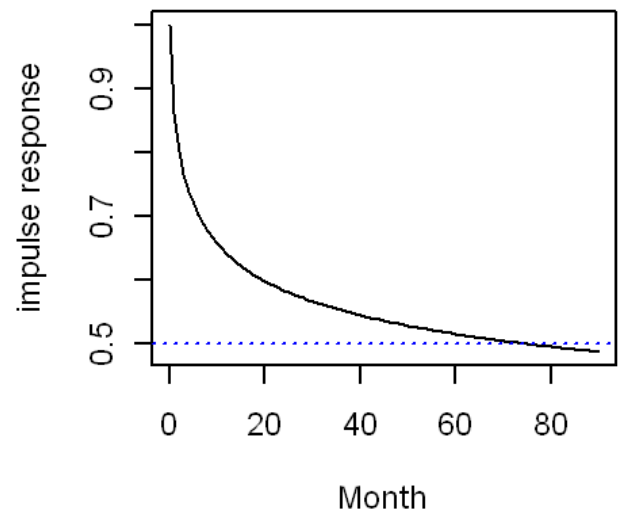


Figure 6. The impulse response function of bilateral exchange rates with respect to Germany

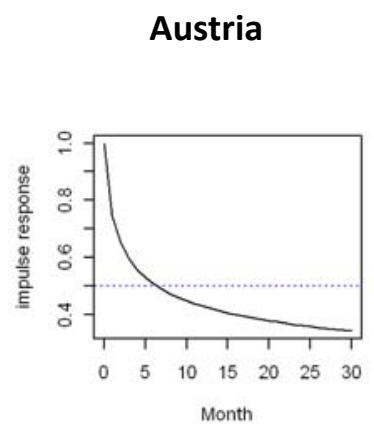

Danemark

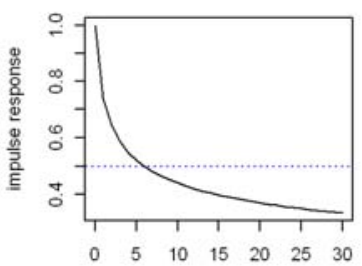

Month
Belgium

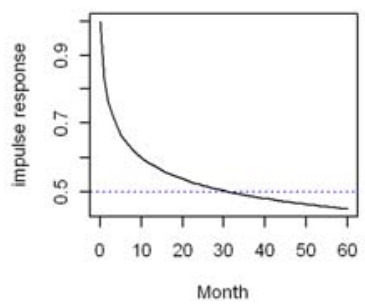

Greece

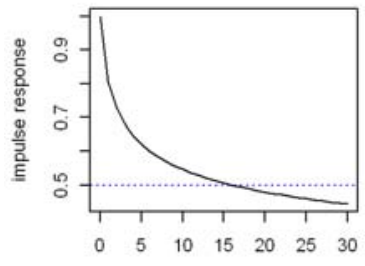

Month

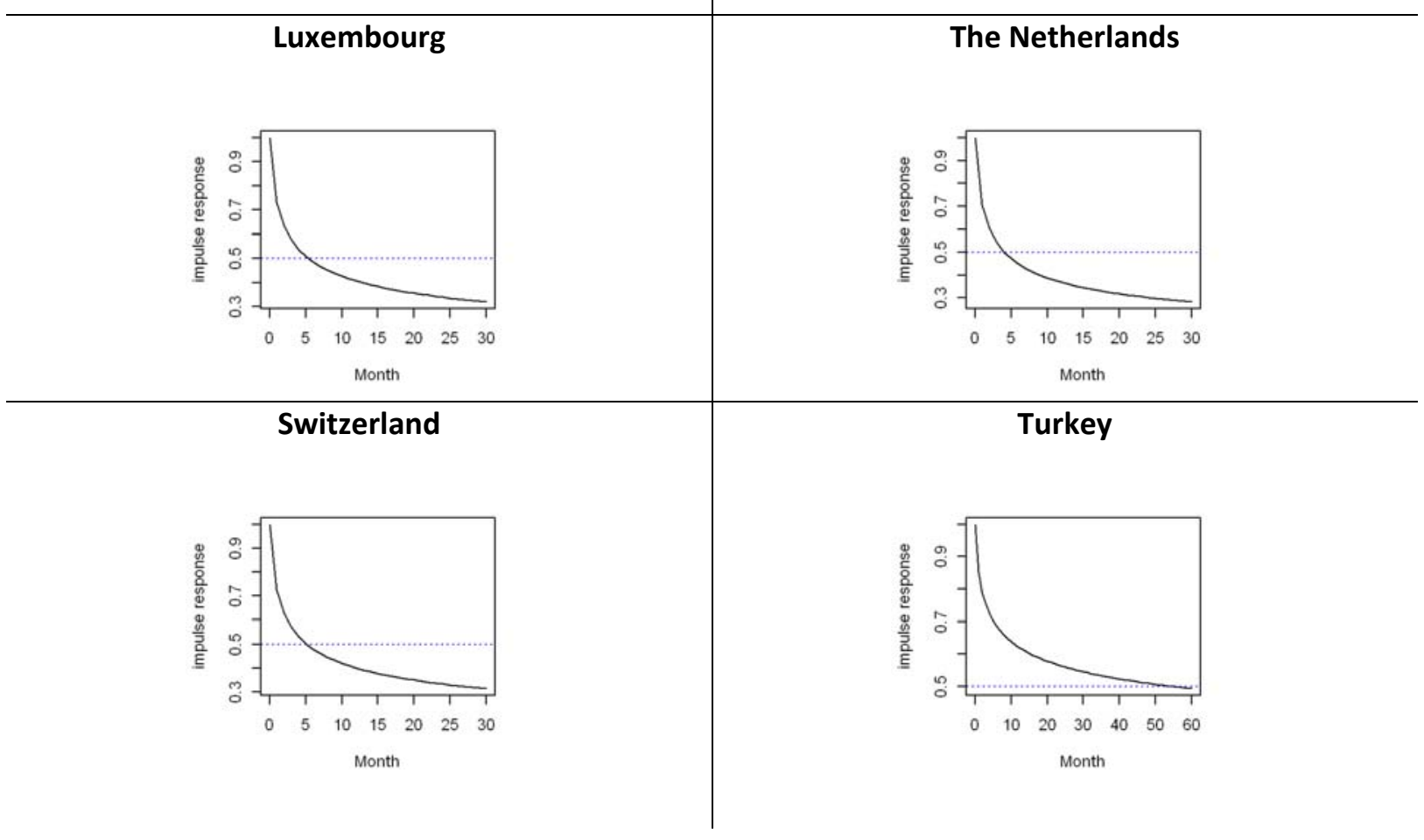

